


\section{MATADOR - ET KIG IND I GADESPEJLET}

\section{Af Nanna Frost, Holger Knudsen, Sine Dalsgaard Kristensen og \\ Peter Rosenlund Strensen}

\section{INDLEDNING}

Matador er noget særligt! Dette særlige er vi gåt pa jagt efter 1 tre omrader af Matadors kmpetekstkorpus. Det er: 1) seriens hovedfor $1 \phi b$, 2) Matadors univers set 1 provinsanalytisk perspektiv og 3) det kønspolitiske aspekt, der udgør serlens hovedtema.

Den tese, vi arbejder udfra, har vi kaldt den dobbelte brugsvardi. Dobbeltheden består 1 seriens evne til på en og samme gang, at opfylde seerens forventninger til lørdagsaftensprogrammet i TV, nemlig: hygge, morskab, genkendelighed, overskuelighed og harmont, samt seerens behov for exkendelse og indsigt $i$ forhold til egen tilvaxelse og samfundsmzsig virkelighed.

Artiklen er i фvrigt skrevet pä baggrund af udvalgte problemstillinger fra eksamensopgaver skrevet 1 sommeren 1981 og bygger pa analysex af episode 13-18, der blev sendt 1 november 1980 til januar 1981. Resumeer af disse episoder findes efter artiklen.

\section{HOVEDFORLดBET I MATADOR}

En stor del af tekstmassen 1 Matador har form af konflikt- og harmoniforl $\phi b$. Dvs. handlingsfor $1 \phi b$, der via den samlede betydning $i$ et antal scener opstiller en konflikt, som 1 resten af forlobet finder en $1 \phi$ sning og saledes ender $i$ harmoni. I det omfang at denne konflikt er en parallel til konflikter $i$ modtagerens hverdag, fremkalder I has valgt at kalde harmonisering.

Den mest omfattende form for harmonisering fremkommer, når en kontradiktorisk konflikt harmoniseres. Den kontradiktoriske konflikt ex en konflikt, der egentlig er uløselig inden for det borgerlige samfunds rammer 1 modsatning til den kontrere konflikt, der lader sig $1 \phi$ se inden for disse rammer. Harmoniseringen af den kontradiktoriske konflikt foregår $i$ to faser. I forste fase fordrejes den u- 
lфselige konflikt allerede ved dens fremkomst 1 handlingsforlфbet

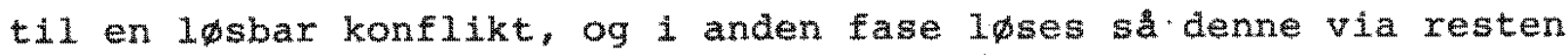
af handlingsforlobet. I Matador løses de kontrare konflikter pa en af følgende to måder: 1) udgransning, hvor en af rollerne udvikles til en skurkerolle, der giver mulighed for udgransning af skurken eller de af skurkens kvaliteter, der star i vejen for 1osningen. 2) medieringen, hvor modsatningen forskydes til nye modsætninger eller udvides, sả de bliver medierbare ved hjelp af et tredje standpunkt eller kvaliteter, der knytter sig til en tredje person.

Hver episode 1 Matador ex komponeret sadan, at den indeholder to til tre af den slags konflikt- og harmoniforlфb, varieret med mere enkeltstånde scener, der enten afslutter forløb fra de foregånde episoder eller lagger op til nye handlingsforl bb 1 de komende. Med denne lidt indviklede fortallestruktur opnar producenterne at gфre den enkelte eplsode meget handingsmattet og oplevelsesrig for seeren, selvom det enkelte handingsforløb egentlig skrider ret roligt fremad. Samtidig sprger rigelige aktualiseringer af hengemte konflikter for, at det enkelte forlob alligevel bliver overskueligt pa trods af mangfoldigheden.

Dertil kommer imidertid, at samtlige 24 episoder lader sig lase som ên lang fortælling. En fortalling, der ogsa er struktureret som et konflikt- og harmoniforløb, 1 det efterf $\phi$ lgende kaldet hovedforl $\phi$ bet og hovedkonflikten. Denne hovedkonflikt udspilles pa overfladen som en personkonflikt mellem opkomlingen Mads skjern og det etablerede borgerskab 1 Korsbak med Hans Chr. og Maude Varnas 1 spidsen for et sandt galleri af mere eller mindre finurlige personex. Bagved denne personkonflikt tematiseres endvidere en normkonflikt mellem de normer, som de enkelte personer er barere af. Denne konflikt harmoniseres sammen med personkonflikten gennem det samlede forløbs udgransninger og medieringer til en normmxsig midterposition, som vi vil fors $\phi g e$ at påvise $i$ det f $\phi 1-$ gende. Hovedforl bbet sammensattes med andre ord af de enkelte konflikt-og harmoniforløb, der ret umarkeligt flytter om pa normerne 1 Korsbak-universet. De enkelte handlingsforl bb er tilknyttet hovedforløbet på én af følgende tre mader: 1$)$ handlingsfor $1 \phi b$, 
der gennemsplllex deres egen konflikt til en losning og samtidig driver handingen i hovedforlobet fremad. 2) handingsforlob, hvor hovedkonflikten kun ex tilknyttet som en af arsagerne til at konflikten opstar. Dlsse forløb viser, hvor stor indflydelse den far for hele livet 1 Korsbxk og understregex saledes dens betydning for Korsbakuniverset som helhed. 3) skamte- og skandaleforl $\phi b$, hvis brugsvardi forst og fremmest er morskaben. vi har varet nodt til at udelade analysen af denne forlobstype, men vil dog her fremheve, at disse forl $\phi b$ med deres latterliggфrelse af bestemte normer og personer virker underst $\phi t$ tende $i$ forhold til hovedforl $\phi b e t s$ budskab.

Hovedfor 1 bet 1 episode $1-12$

Allerede ved ankomsten $t 11$ korsbak kommer Mads skjern 1 konflikt med den førende Varnæs-familie og dens omgangskreds. Først fordi han opretter en konkurrerende forretning t11 Arnesens, derefter fordi Hans Chr. nagter Mads et Ian af hensyn til vennen og familiemedlemet Arnesen. I lobet af disse episoder udkonkurreres Arnesen, der begar selvmord samtidig med, at фkonomien begynder at vakle 1 Varnæs-banken, Mads skjern vinder stadigt $\phi k$ onomisk terran. Han hidkalder sin bror Kristen for at oprette en konkurrerende bank, omegnsbanken.

Samtidig med denne økonomiske udvikling fremarager de enkelte for$1 \phi b$ normforskellene mellem de to familier som arsag til de $\phi k o n o-$ miske forandringer. På skjern-siden er det isar de rent pkonomiske kalkulationer kombineret med Mads' indremissionsk pragede arbejds- og afholdenhedsmoral, der dominerer. pa Varnas-siden er det stiv borgerlig dannelse kombineret med luksusforbrug og elskovseventyr, der afstedkommer en del ulykker. I løbet af de 6 første eplsoder opstilles en normkonflikt, som kan beskrives følgende skema:

BEHERSKELSE

skjern-siden. Positivt valoriseret.
DERADENCE

Varnes-siden. Negativt valoriseret. 


\begin{tabular}{c|c} 
Skjern-siden. & Varnas-siden. \\
arbejdsmoral & \\
ariftsstyring & nydelsesmoral \\
tolerante ongangsformer & ariftsafhangighed \\
fornuftsbestemthed & hieraxiserende omgangsformer
\end{tabular}

Disse normpositioner og den værdi, de tillagges, forandres nu så småt i lobet af episode 7-12. Forandringen foregar ved en fordeling af det positive på enkeltpersoner på skjern-siden, idet brødrene Mads og Kristens deltagelse 1 en korruptionsaffare og Kristens giftermål med Iben $g \phi r$ dem mindre moralsk uangribelige, mens. Ingeborgs mere tolerante og humane egenskaber bevarer deres positive værd1. P\& Varnæs-siden breder dekadencen sig til Hans Chr. Varnæs, hvis elskovsaffære med en bankassistent truer hans familieliv. Og hvor Vicki Arnesens lyst til at vare skuespiller iscenesattes som en social deroute. Kun Elisabeth Friis skildres med positiv vardi, ikke mindst fordi hun støder an mod den stive borgerlige dannelse med sine meninger on fri abort, der 1 ovrigt ogsa vakker forargelse i størsteparten af det $\phi$ vrige korsbæk-univers.

Hovedforløbet i episode 13-18

Salledes står brikkerne, da Matador-spillet atter tager sin begyndelse 1 episoderne 13-18. Oversigtsmassigt fortsætter hovedkonflikten 1 disse seks episoder og Varnæs-sidens sociale nedtur fortsætter til den når sit nulpunkt i slutningen af episode 16, mens Mads skjern befæster og udbygger sin Matador-stilling til nærmest koncernagtige former.

VARNRS-SIDEN: I løbet af de tre første episoder findes der tre forl $\varnothing b$, der tematiserer varnæs-derouten og stigende afhængighed af Mads. Skjern og Skjold Hansen. Det første forløb er konflikten om besættelse af embedet som organist i Korsbæk Kirke, hvor Elisabeth Friis og lærer Andersen er ansøgere. Det er menighedsradscormanden, Mads Skjern, der skal afgфre valget mellem de to an- 
sфgere. Inden afgørelsen har Elisabeth Frils demonstreret ved en koncert, at hun er bedst kvalificeret, så for Mads står valget mellem saglighed over for onsket on havn over varnas-familien. Mads halder til havnen, der dog ogsa begrundes med hans indremissionske forargelse over Elisabeths holdninger til abort. Undervejs 1 forl $\phi$ bet overtales han dog af Ingeborg til at ansste Elisabeth, hvorved hendes forbliven 1 Korsbak sikres, mens larer Andersen, der 1 forvejen er tillagt skurkerolle, bliver udgrenset, og forløbet kan ende 1 harmoni. Men samtidig er Mads Skjerns renlivede afholdenhed og havntorst yderligere blevet skilt ud fra Ingeborg skjerns saglighed og tolerance. Dette gentages nu stort set 1 konflikten omkring Vicki Arnesens ansattelse som lærer på privatskolen $i$ Korsbak. Hendes egenskaber er blevet andret ved samværet med Herbert Schmidt, hun har opgivet sin skuespillertilvw relse og med en nyligt afsluttet lærereksamen sфger hun nu arbejde $i$ korsbak. At det er slut med driftsafhangigheden overbevises seeren allerede om 1 den indledende festsekvens, hvor hun afviser tilnermelser fra den unge Gustav Frils. Hendes normskift er gennemf $\phi \mathrm{rt}$, omend ikke sa vidtgâende som Mads' renlivede beherskelsesposition. Hun far da ogsa stilling ved endnu en udgransning af lam rer Andersen.

Den tredje konflikt opstâr mellem Mads skjerns arbejdsmoral og Jørgen Varnæs" mere nydelsesdominerede moral. I forste ongang må Jorgen Varnes godtage arbejdsmoralen 1 form af fast arbejdstid og underkastelse under Mads" ledelsesret. Men undervejs i forl $\phi-$ bet udvides konflikten ved at Jorgen Varnas blaser pa sine arbejdsforpligtelser og Mads" bestemmelsesret for at tilbringe en kampejuleferte sammen med sin elskerinde, dex bor i Schweiz. Derved kobles nydelsesmoralen sammen med ariftsafhangigheden, og denne dekadence straffes af Mads Skjern, ldet han lader Jorgen Varnæs nфjes med at arbejde på honorarbasis.

Men Jorgen Varnzs kan likke leve af det lose arbejde alene og overtaler Hans Chr. til at gâ tiggergang til Mads og bede ham om, at Jørgen Varnas kan $\mathrm{f}$ lov at arbejde for begge de konkurrerende kapitaler. Denne scene er den endelige udsoning af den uretfardige behanding, Hans Chr. gav Mads, da han kom til Korsbak. Verbalt 
antyder han en indrommelse af sine fejl og gentager den 1 en efterfølgende scene over for Jørgen Varnas. Desuden rumer scenen ogsa visuelle tegn pa det andrede styrkeforhold: rumsligt foregår det pa Mads' hjemmebane og på Hans Chr.'s initiativ. Og hans mimik ex høflig og underdanig 1 kontrast til Mads, der er kold og forretningsmassig. Men Mads" nervфsitet for Hans Chr. "s ankomst røber for tilskueren, at han ved, hvad der er pá spi1. Mads ind-. villiger 1 Hans Chr.'s forslag, og konflikten ender i midlertidig harmoni. Med denne scene er Hans Chr. nu tilpas ydmyget til, at han kan tages til nade og indga $i$ blokken af overvejende positivt skildrede personer, mens Maude og Jorgen fortsatter ad dekadencens vej indtil videre. Jorgen dog kun 1 sin fritid.

SKJERN-SIDEN: Tendensen til udspaltning af positive og negative kvalifikationer pa henholdsvis Ingeborg og Mads fortsetter 1 to forløb, der henholdsvis er barende $i$ episode 14 og 15.

Det forste forl $b \mathrm{~b}$ drejer sig primart on den palidelig ekspedient Arnold Vinther, der bade fungerer som kontrast til den upalidelige Jørgen Varnas og selv gennemlober en kombineret kærlighedsog social konflikt. Han misforstar nogle antydninger fra Mads og tror, at han skal vare direktor, derfor vil han $\mathbf{1} 1 \mathrm{~g}$ op med sin hidtidige elskede, damefrisør Agnete Hansen, som han nu anser for at vare et upassende part1. Det er forsavidt hans gode ret, men handlingsforl bbet lader drifterne lobe af med Arnold, hvorved den mere moralske konflikt mellem den seksuelle udfoldelse sammen med Agnete og forpligtelsen til at tage ansvaret for sine hand1inger, dvs. at gifte sig med den forelskede og besvangrede kvinde. Eller i korthed: ren driftsafhængighed versus kernefamilie. Derefter ryddes misforstäelsen af vejen, hvorved ogsa konflikten mellem social position versus karlighed trylles bort, desuden gor forlobet den rene driftsafhengighed umoralsk ved at lade Arnold fremsxtte krav om, at Agnete skal fa foretaget en illegal abort. Endnu engang griber Ingeborg ind, den rene ariftsafhangighed udgranses. Ldet Arnold og Agnete ender 1 kernefamiliens harmoni.

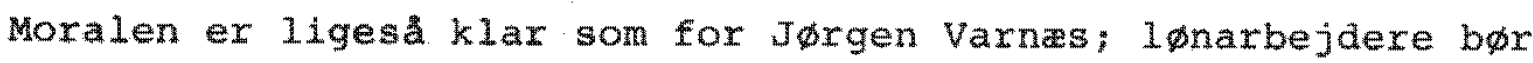
ikke alene vare pligtopfyldende, men ogsa have styr pa deres drifter. 
Forløbet udskiller Mads" rent $\emptyset$ konomiske interesser 1 I derne over for Ingeborgs menneskelige interesse 1 samme. Hun ved, hvad der ex til Arnolds eget bedste, endda bedre end han selv. Differentieringen fortsxtter 1 Anna-forlobet, der er bærende 1 episode 15, og som gennemspiller en rakke konflikter mellem Annas puritanisme og Iben, Ingeborg og skjernmbonenes holdninger. Men dex opstar ogsg spandinger mellem Anna og Mads, der viser sig at have bevaget sig et stykke bort fra Annas normer, men alligevel lkke langere end at han rumer samme selvbevidste intolerance, som Anna plager sine omgivelser med. Denne lighed mellem Anna og Mads frentrader isar to stedex. I en scene, hvor de diskuterer mesalliancen mellem Iben og Kristen, bruger Mads, der er presset, Annas vaben 1 diskussionen, nemilg bibelcitater. Han siger: "Jeg er ikke min broders vogter". Citatet er fra forfatterens hånd valgt sadan, at Mads er sig sit medansvar bevidst, samtidig med at han bruger dette citat til at afvise medansvaret over for Anna. Citatet er nemlig kains svar til Gud efter drabet pa sin bror Abel. Hans bekymrede og rugende mimik, der 1 denne scene vendes bort fra, avs. skjules for Annas synsfelt, visualiserer samme indre modsxtning og peger frem mod den gentagelse af fejlen, som Mads begår 1 forhold til datterens giftermal, nemlig okonomiske kalkulationer ind over kxlighedsanliggender. Ligheden fremtrader ogsa 1 slutscenen, hvor skurken Anna udgranses af korsbæk-universet. De har samme stive kropsholdning og samme sammenbiate minik, der vises $i$ nerbilleder. Ja, Mads fremtrader enda hardere end Anna, idet hun beveges af Ingeborgs tolerance, mens Mads forbliver urokket fjendtlig. Forlфbet demonstrerer saledes bade den samme selvbevidste intolerance og de forskelle, der er opstalet med hensyn til graden af afholdenhed og synet på arbejdslon, hvor Mads virker helt frivol i sammenligning med Anna.

LAURA-KONFLIKTEN: Krumtappen 1 hovedforl $\phi$ bet ex konflikten mellem Laura og hendes arbejdsgiver Maude i episode 16. Denne konflikt indlejres $i$ hovedforlфbet via et par scener, der modstiller Ingeborgs menneskelige interesse for lonarbejderne med Maudes tilsidesattelse af arbejasaftaler. Derved forskydes kontradiktionen: Ionarbejde versus kapital til intimsferen og fremtrader som den kontrære konflikt mellem menneskelig interesse og udnyttelse af lon- 
arbejderne. I første omgang forbliver Laura loyal, men 1 det trefasede forl $\phi b$, der gennemspilles 1 eplsode 16, kommer jordskalvet.

Første fase er en medaljeoverrakkelse, der skulle være en passkønnelse, men pinagtigt tydeligt overbevises forst seeren og siden Laura om herskabets reelle interesseløshed. I stedet for integram tion og samarbejde blotlægges de reelle klasseforskelle. I anden fase siger Laura op, flytter fra Varnas-hjemmet og begynder en tilvarelse som $1 \phi s$ kogekone, hvorved hun stifter bekendtskab med endnu varre arbejasgivere. Maude oplever hendes flytning som en katastrofe leffektfuldt skildret 1 krydsklipning med folks reaktion pa besættelsen). Desuden fungerer Lauras afrejse som mark $\phi r$ af nastsidste trin pă Varnas-familiens deroute. Bruddet sender seerens fllelser ud 1 ambivalens mellem fryd over Lauras frigørelse og medildenhed med den hardt provede Varnas-familie ved tabet af det eneste stabile moment $i$ deres del af Korsbak-universet. En ambivalens, der underbygger den gradvise omvurdering, der sker fra negativ til positiv vardi pa varnas-siden, efterhanden som normerne andrex $\$ i g$ og harmoniseringen af hovedkonflikten namer sig.

Harmoniseringen af Laura-forlфbet pabbegyndes samme sted 1 teksten, som derouten năr sit nulpunkt, nemilg et alsangsagtigt mode on anlaggelse af en folkepark. Maude er ved en misforstâelse kommet med til modet, der viser sig at vare et socialdemokratisk komplot. Sekvensen har to resultater: 1$)$ et forste skridt, omend nødtvunget, mod harmoniseringen, idet Varnæs, skjold Hansen og skjern mal allere sig mod angrebet pa deres sommerhuse. 2) alliancen ledes af Mads, hvorved nedgangen 1 social status bliver abbenbar for selv Maude Varnas, der indleder et kxmpeskænderi med Hans Chr. pa hjemvejen. Varnas-familien har naet sit nulpunkt.

Her treder Laura bogstavelig talt atter ind 1 billedet, og tredje fase, hjemkonstfasen, er 1 gang. Laura kommer atter tilbage $t 11$ "sit" køkken og genansattes pa Hans Chr."s initiativ, harmoniseringen ex $i$ hus. Konflikten udnyttelse versus menneskelig interesse blev udvidet til en mere vidtgående konflikt mellem hărdere udnyttelse end Maudes og Ingeborgs menneskelige interesse, og det giver 
plads for mediering ved hjwlp af Hans Chr."s menneskelighed, kombineret med Lauras affinden sig med den relativerede udnyttelse. Herved henter seeren sig 1 tilgift til harmoniseringen en gedigen hjalpe til selv at affinde $\mathbf{s i g}$ med dennes eget konfliktfyldte 1 onarbejderliv. Med Lauras tilbagevenden har Varnæs-familien allerede taget det forste skridt bort fxa deroutens nulpunkt, det er faktisk den forste entydigt positive begivenhed, der ex handt dem 1 episode 13 til 16.

SKJERN-SIDEN: Efter Laura-konflikten udbygges udspaltningen pa Skjern-siden. Mads fortsetter sine okonomiske kalkulationer ind over intimsfaren. Mod Ingeborgs vilje tvinger Mads, pa grund af sine normer, Daniel ind 1 en uddannelse, der negligerer hans kreative interesser og kvalifikationer. Og $i$ et kærlighedsforl $\phi b$, der langt hen er parallelt med trekantforholdet mellem Iben, Kristen og Elisabeth stotter Mads alliancen mellem Mogens og datteren Ellen, mens Ingeborg har sin tvivl. Denne gang er det ulrik varnas, der trakker det korteste stra, men harmonien opret-

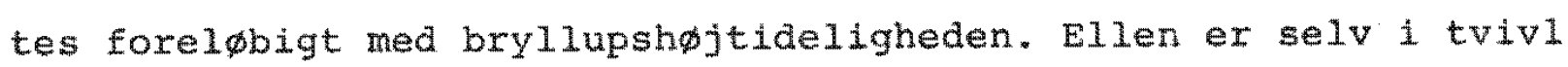
om forehavendet, men Mads st $\phi t t e r$ forbindelsen ud fra to motiver. Dels de okonomiske muligheder, der ligger 1 forbindelsen til Mogens's far, dels onsker han at undga slagtskab med Varnas-familien.

VARNES-SIDEN: Pa Varnæs-siden er derouten standset, men der $1 \phi b e r$ en konflikt, der egentlig allerede startede $i$ episode 13 mellem Maude og hendes born. Den tematiserer Maudes manglende opfyldelse af bornenes kerlighedsbehov, făr et nyt toppunkt i konflikten omkring kondomautomaten og slutter uharmoniseret med, at bornenes had og frustration kommer t 11 fuldt udtryk, da ulrik med gradkvalt steme skælder Maude huden fuld og som konklusion raber: "Du har aldrig brudt dig om andre end dig selv!" Maude synker sammen pa en stol og stirrex ud 1 luften, endelig beviast om sin egen menneskelige afstumpethed, inkompetence og egocentricitet.

Dette er Maudes personlige nulpunkt, men selvom denne konflikt ikke harmoniseres for indevarende, sa overlejres den af harmonien fra det andet for $1 \phi b$ i episode 18 , hvor jøden steins redning ud- 
virkes af Maudes medmenneskelige og selvstandige indsats. Foruden forl pbets egen spanding fungerer det ogsa som naste trin pa harmoniseringens vej. Redningen bliver nemlig et falles projekt for de centrale varnas-personer, hvor isar Maudes deltagelse er vigtig, fordi hun var den sidste hindring for harmoni pa varnas-siden og for de halventrale personer Kristen, Danlel og Larsens pa Skjernsiden. Her trader menneskelighed og tolerance ind som fallesnevner, en fxlles kvalitet hos begge familiex 1 konfrontation med tyskernes intolerance og umenneskelighed over for jøderne. De indbyrdes nomforskelle lader sig reducere til 1 ighed 1 sammenligning med den fælles fjendes normer. Uden for denne harmoni stăr dog stadig Mads, der t11 gengæld har oparbejdet en hardhed, som det nok vil tage endnu seks episoder at fa bugt med.

\section{Normkonfliktens "1申sning"}

Normkonflikten tegner til at blive medieret omking en midterposition, som vi har kaldt bemestringspositionen, og som vi vil beskrlve ved hjalp af nedenstånde skema.

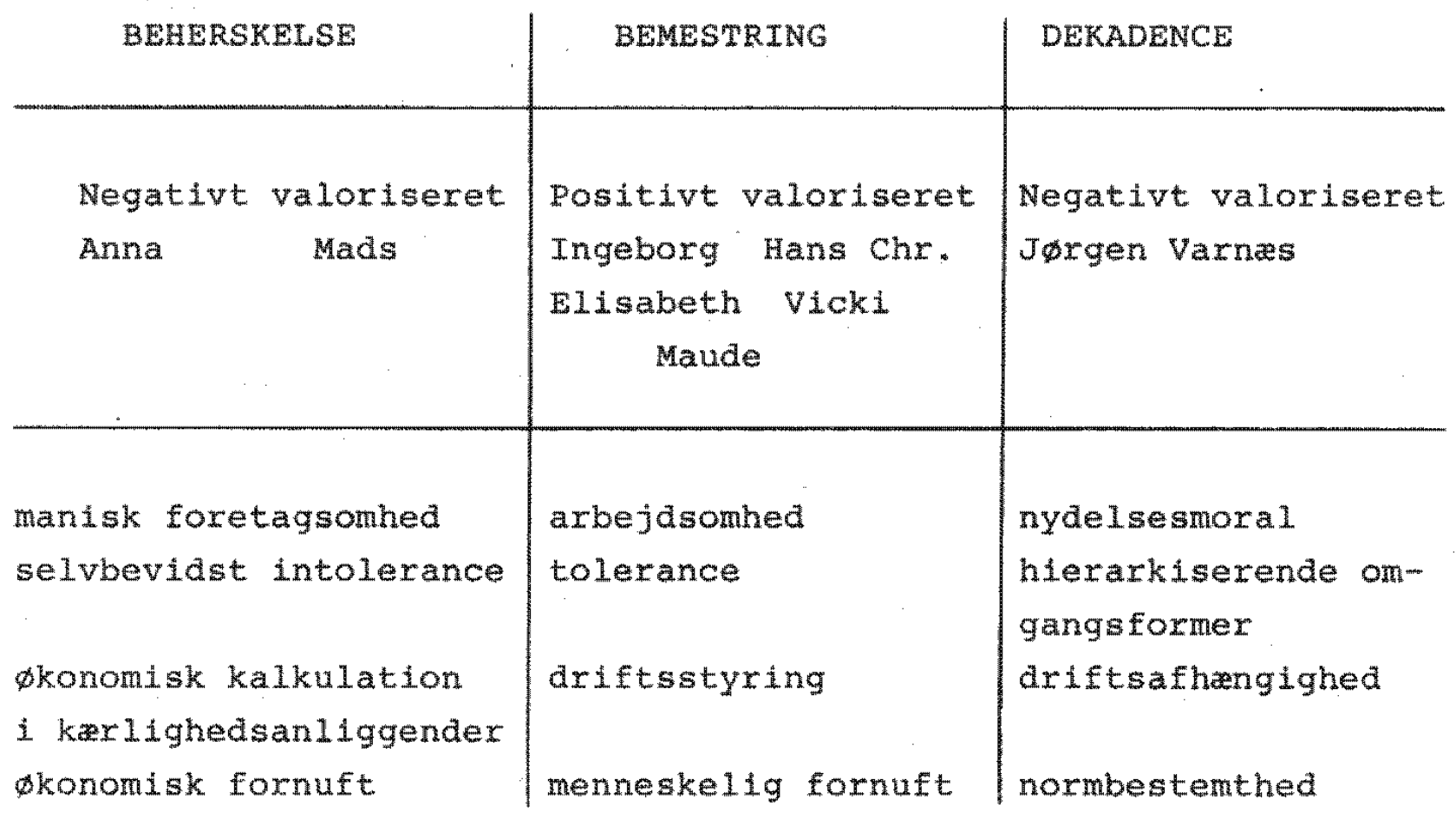


Som seere følger vi, at hovedforløbet lader forskellige fraktioner af borgerskabet 1 korsbak forbrodre sig pa denne normposition, mens staig fastholdelse af den rene beherskelse ellex dekadencen trues med undergang.

Hovedforlobets omrokering af personernes normex og udspaltningen af kvaliteter skiller efterhanden de oprindelige normer sa langt fra hinanden, at der bliver plads til den mediering som vi har kaldt bemestringspositionen. Denne har for sa viat hele tiden varet til stede hos personerne Ingeborg og Katrine, men den gores stadig mere signifikant og positivt valoriseret undervejs i hovedforlobet. Det sker i takt med at den rene beherskelse bliver negativt valoriseret og dekadencen opgives af stadig flere medlemmer af varnas-familien til fordel for bemestringspositionen. Efterhanden som personerne indfinder sig pa denne, skildres de med overvejende positiv val $\phi r$, efterfulgt af seerens sympati og identifikation. Afkodningen af hovedforlobet domineres af en mulighed, bemestringen er vejen til hamoni.

Denne virkning forstarkes af sammenkoblingen mellem de enkelte forlфb og hovedfor $1 \phi b e t$. De enkelte forl $\phi \mathrm{b}$ denonstrerer, hvorledes hom vedkonflikten og normerne bag den afstedkommer pinlighed, spandinger, ulykker, brud og disharmoni ikke alene for de centrale personer, men efterhanden berøres de fleste personer 1 Korsbak-universet af konflikten $i$ storre eller mindre tidsrum. Derved ophobes et stadig storre behov for hoveakonfliktens bileggelse hos seeren. Dette forstarker godtagelsen af den bemestringspositionen, som kan bringe konflikten ud af verden. Den modtages $i$ glade og med fuld musik.

Det man modtager er faktisk en undsigelse af den arbejasfrie nydelse og den altfortarende lidenskab samt nogle stive omgangsformer, der skulletjene til at fortrange det ubehagelige, men som tvartimod fremkalder pinlighed. Som alternativ fremholdes benestringen, der ogsa er kompromis $i$ forhold til den forkrampede beherskelse. Denne bemestring fremkommer imidlertid ved en spaltning af beherskelsespositionen og det tilsyneladende kompromis kraver ret beset lige sa vanskeig selvaisciplinering som beherskelsen. 
Den stadigt mere maniske foretagsomhed, der udvikles hos Mads, ex udspaltet fra den arbejasomhed, pligtopfyldelse og palidelighed, som Ingeborg ex barer af, og som Varnasfamilien antager. Den forudsætter evner til at kunne pendle mellem nydelse og pligt, evne til bestandig ny selvdisciplinering. Her har den konstant disciplinerede dog $i$ det mindste vanen som hjælper.

Ligeledes hjælpes den selvbevidste intolerance af at kunne afgranse sig totalt fra det, der er skrmmende, truende, uforstaeligt anderledes. Den tolerante ma derimod kunne beherske sin angst, for det dex er anderledes, for at kunne vare imødekommende, aben og overbarende.

Lidt anderledes forholder det sig med driftsstyring, her udspaltes først og fremest okonomiske kalkulationer ind over karlighedslivet som uacceptabelt. Serien fastholder parforhold baseret pa karlighed og ansvarlighed som det alternativ, som de driftssafhangige Varnasser ma aname eller glil til grunde. Psykisk set er det altså her stadig den rene beherskelse, som serien fremlagger, men den iscenesettes som komproms via udgransningen af Mads' uacceptable kalkulationer.

Endelig udspaltes den isolexede фkonomiske fornuft, som Mads reprasenterer, fra den menneskelige fornuft, dex sфger andre glader end kapitalakkumulation og udvidelse af det territorium, man behersker. Her er ikke tale om forskellige beherskelsesformer, men om en iscenesxttelse af den menneskelige fornufts dominans over den фkonomiske fornuft. Nar det kan virke trovardigt, skyldes det en forskydning undervejs i hovedforl $\phi$ bet bort fra den $\phi$ konomiske konkurrencekamp, som skubbes diskret i baggrunden til fordel for intimssfareproblemer, der ikke 1 så direkte forstand plages af $\varnothing$ konomiske tvangsmekanismer.

Sammenfattende ma man sige, at der sker en udvikling 1 storforl $\phi-$ bet, hvor dele af beherskelsespositionen forkastes til fordel for andre beherskelsesformer, mens andre dele blot flyttes over 1 medieringsfeltet. Det psykiske grundlag er stadig beherskelsen, man bør prastere en passende beherskelse, ellers gar det ildel Matador er et moralsk spil. 
I det foregående har vi set, hvordan konflikt-harmonistrukturen

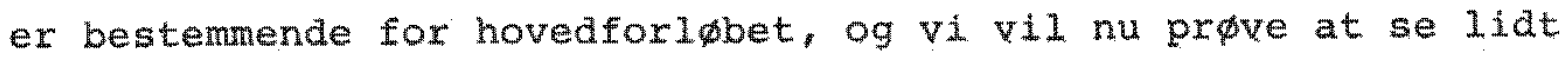
narmere $p a ́$ personernes indbyrdes relationex 1 miljpet. Derved kommer vi endnu engang ind pa spørgsmalet om historicitet, men her er synsvinklen en anden. Korsbakmiljøet rejser en provinsproblematik, der rumer mulighed for en anden historiebevidsthed end den, hovedforl $\phi b e t$ formidler. Nermere herom senere. Vi indarager den nyere krttiske provinsforskning inden for litteratur-og samfundsvidenskab for at kaste nyt lys over bestemte problemstilinger, som i forste omgang har noget med provinsbyen Korsbak at gøre ${ }^{1)}$. Fx. kan man fokusere pa, hvorfor kapitalismen i Mads Skjerns skikkelse lkke satter sig modsatningsfrit og restlфst igennem her. Herved kommer vi ogsa ind pa, hvorfor Matadox skaber sa stor genklang hos seerne, hvilke behov modet med et historisk provinsmilj fra $30^{\prime}$ erne og 40'erne kan imddekomme. Det forekommer narliggende at navne seriens morskab og harmonisering som forklaring, men den er jo ogsa problembehandlende, ikke kun passiviserende. Vores tese er, at seerne far aktiveret enten en personlig exindring om perioden og lignende miljøer og/eller en slagtshistorisk erinaringsrest ${ }^{2}$ ) om en forholdsvis mere overskuelig og selvforvaltet samfundsorganisering. Denne forestilling kan virke tiltrakkende på det moderne $80^{\prime}$ er menneske, der oplever sin egen hverdag som bruafyldt og noverskuelig. Vi mener, udslaget ikke kun bliver en regressiv, nostalgisk begradelse af tabt idyl og overskuelighed, men en kim til oparbejdelse af historisk bevidsthed, som indebarex, at historien opleves konkret som foranderlig og dexfor udløser nogle håb og фnsker om en anden fremtid. Denne form for historicitet besvarer ganske vist heller ikke, hvorfor andringer bliver mulige og nфdvendige. Til gengeld visualiseres i Matador en historisk periode som en brydningstid med bade integritet og konflikter/brud pa et lokalt og personligt-livshistorisk plan. Det, mener vi, kan aktivere subjektive behov for andringer, som naturligvis ex lige sa nodvendige som en mere objektiv begribelse af historien. Det er den dobbelte brugsvardi, som vi for har talt om, nemlig harmonisering og overskridelse, vi vil forsфge at păvise med provinsforskningens begrebsapparat. 
Forst må vi slá fast, at provinsbegrebet dakker over andet og mereend en geografisk størrelse, nemlig фkonomiske og ideologiske særtrak, aer kan forekomme både $i$ stowbyen og pa landet. Fleming Arentofts definition kan referere t11 bade Korsbakuniverset og nutidige Iivssamenhange:

Den geografiske dimension af den beskrivende art er blevet underordnet det ideologiske monster. Provinsbegrebet er blevet til ideologi. I forhold til Kobenhavn er det regionernes og byernes karakter af smaborgerilghed, af snaverhed og restriktioner, praget af de mindre dimensioner, der er afgorende. (...) Provinsen som ideologisk struktur, pahæftet disse betydninger, er 1 sin oprindelse centerorienteret, udviklet og báret af det akademiske borgerskab 1 centret. Det er ikke "provinsen" selv, der er oprindelsen til provinsideologien. Befolkningen 1 periferiomraderne ex 1 det hojeste underlagt denne ideologi som et kollektivt mindrevardskompleks. . 3)

I Korsbak ses, hvordan forholdet til kobenhavn er praget af dette "kollektive mindrevardskompleks" som isex det gamle borgerskab forsфger at overvinde ved at tillagge sig en 'adxkvat' 'Iivssti1. I episode 13, "Et nyt 1iv", udgor Varnæs" fransk-inspirerede fest et komisk eksempel pa denne straben.

Imidlertid har der ogsa historisk set varet gjort opror mod provinsideologien, og i Matador reprasenterer Katrine mest typisk denne modstand 1 og med hendes sterke grundtvigianske r $\phi$ dder og tilhørsforhold til partiet venstre. Hun står for en dannelsestradition, som bevidst hax gjort op med provinsideologien pa et bestemt historisk tidspunkt ved at manifestere en kulturel og ideologisk provinsidentitet i forbindelse med bondernes hojskole- og andelsbevagelse, venstrepressen $\mathrm{m} . \mathrm{m} .{ }^{4)}$ Det er betegnende, at denne tradition, der startede i sidste tredjedel af 180o-tallet, er vigende i 30'erne, men hos katrine lever stærkt som ideologisk monster. Den kapitalistiske udvikling foregăr netop ikke uden hindringer. Her kommer vi ind på Blochs begreb "usamtidighed", der betegner det forhola, at

...der pa en og samme tid og modsigelsesfuldt eksisterer bade fuldt udfoldede kapitalistiske og et "efterslab" af forkapitalistiske produktionsforhold og ideologier.5)

Det er dog vigtigt at huske pa, at usantidighed ikke behøver at. betegne noget tilbagestaende 1 reaktionar forstand. Katrines 
tilbageholdenhed med at lade sine penge arbejde for Mads" kapital indeholder en moralsk uvilje mod den kapitalistiske udvikling, som Mads reprasenterex. Usamtidigheden eksisterer ikke som ren kategori. Den aktiveres som modstandsform undex kapitalismen og kan namere betragtes som proces end som tilbagestaende, statisk livsform.

I korsbak er $\phi$ konomi og moral tat forbundne storrelser, hvilket ovenstående eksempel også viser. Begrebet moralsk $\phi k o n o m i{ }^{6}$ betegner en organisering af samfundslivet, som oprindeligt horer til $i$ et forkapitalistisk samfund. Den overlever som modstandsform under kapitalismen iser 1 forbindelse med smaborgerskabet, der star uden for den direkte vardiakkumulation og dermed klassekampen. I Matador smitter den moralske фkonomi ydermere af som klassemedierende faktor i forholdet mellem proletariatet, isar tyendet, og borgerskabet. Dette kan aflases 1 fx. Lauras loyale holdning til sit herskab.

Småborgerskabet havde sine forudsatninger i det feudale system, hvor фkonomi, politik og (religiфs) moral var vavet snevert sammen. De фkonomiske forhold under kapitalismens udryddelse af smaejendommen og polarisering af samfundsklasserne blev ikke betragtet og kritiseret ud fra rent okonomiske kategorlex af dette usamtidigtanakronistiske smaborgerskab. (...) Det overoranede begrebet var en hojere retfardighed, som med okonomiske baggrund 1 akvivalensbyttet... skulle sikre en jevn fordeling af goderne.?)

Hele problematikken om social opstigning, som ex indeholdt i. hovedmodsatningen, viser, hvordan den kapitallstiske udvikling slar senere igennem i Korsbak, usamtidigt i forhold til centret. I den sammenheng er Mads at betragte som 'samtidig'. Ved at udnytte og omfunktionere elementer af en smaborgerlig, indremissionsk opdragelse evner han at tilpasse sig udviklingen og kalkulere rationelt og effektivt. Han imødekomer fx. lynhurtigt behovet for morklagningsgardiner pa besattelsesdagen, iverksatter omsyning af tapper og lagner til t $\phi j$ p.g.a. ravaremangelen og starter som folge af samme en tekstilfabrik (hørvavning). hele hans ydre beherskelse, hans autoritare opdragelsespraksis og strenge arbejdsmoral kommer ham til gode under den sociale opstigning, men ind imellem ma han boje sig 1 konfrontationen med miljøets moralske фkonomi, som han som (uфnsket) tilflytter ikke 
har forholdt sig synderligt meget til. Han mă med fare for sin forretning transportere Rфde til Kфbenhavn i ên af sine vogne for at redde ham fra nazisterne, da Katrine $g \phi x$ ham opmarksom pa, at Rode flyttede gratis for for ham, da han kom til Korsbak. Dette akvivalentbytteforhold, som ogsa indbefatter sadanne tjenesteydelser, er karakteristisk for moralsk okonomi.

Vi har set på provinsbegrebet $i$ forhold til ulige udvikling på det $\phi$ konomiske og ideologiske plan, men en anden vigtig faktor 1 forholdet til seerens oplevelse er hele hverdagslivets karakter af intimitet og bekendthed. Her har $f x$. bysladderen betydning $i$ Korsbak som moralsk normativ instans, der tjener til at fastholde enkeltindividerne $\mathrm{p}$ en bestemt status i forhold til samfundet, men sladderen kan ogsa udtrykke omsorg. ${ }^{8}$ For seeren er sladderscenerne (fx. tirsdagsvisitterne hos Maude Varnas og mandenes snak i jernbanecafeen, med til at opbygge kontinuitet og samenhang $i$ det korsbakske univers, selvom det gentagne monster til tider afbrydes brat, eksempelvis 1 form af nazisternes indtrængen. Ved et teselskab hos Maude kommer hr. Holzer pludse1ig, som Maude tidigere har modt i københavn, hvor hun ikke vidste noget on hans relation til de tyske besattelsestropper. Det antydes, at harmonien ikke er ubrydelig. men at selv Maude kan tvinges ud 1 en stillingtagen.

Som eksempel pa provinsspecifikke konfliktlinjer, vil vi bruge episode 15, "At trenke og tro". Hex er det specie1t en konfirmationsfest, der tematiseres og endda problematiseres ud fra flere synsvinkler. Festen udspringer af traditionen. Den er samlingspunkt for familien, og der er lagt op til en markering af skjerndynastiets position. Imidlertid er dex bade for og efter festen konflikter, som rokker ved konfirmationens samfundsmassige og religiøse grundlag. Faster. Annas tilstedeværelse virker som katalysator for en familiekonflikt med flere aksex, der delvist har baggrund af religiøs uoverensstemelse. Anna og Mads kommer til at reprasentere modsatningen mellem land og by, nellem et naturbundet landbrugssamfund og et begyndende kapitalistisk udviklet bysamfund, mellem religiøst begrundede, puritanske normer og en mere kapitalistisk kalkulerende og fleksibel holdning, delvist mellem religion og ateisme, reprasenteret af Da- 
niel. Provinsproblemet har her en anden dimension. Korsbak fár storbytrak 1 forhold til det "b申hland" som Anna reprasenterer. I hvert fald er der oplagt tale om ulige udvikling. I Jembanecafeen meldes hendes ankomst "helt over fra det morke Jylland" (Larsen). Hele hendes attitude borer prag af vardighed, sammenbidthed og kulde. Kropsholdningen er rank, men ufri, kjolen mørk og takkelig. Det ubehag, hendes tilstedevarelse giver de andre, understreges af mimikken, især Mads og Ingeborgs signaleren til hinanden. Dialogen er neutral og befinder sig pa et konventionelt. konverserende plan, men den kan tolkes som indirekte kritik, og ved kaffebordet bliver stemingen efterhanden pinilg. B1.a. tales der om aflonning af tjenestefolk, og modsatningen fremtrader mellem en smaborger119, religiøst begrundet gerrighed 1 forlængelse af en afkalds- og nфjsomhedsmoral og en mere generos, men kalkulerende kapitalistisk rationalitet. Man kommer først og fremmest til at tage afstand fra fasterens dobbeltmoral, hun er netop gerrig (camoufleret som godgørenhed) og selvhivdende. Imidlertid ligger ogsa til grund for hendes adfard religiost farvet modstand mod kapitalismen. Umiddelbar antipati mod Anna og forskydning af sympati til Mads slorer imidlertid denne kritik.

Korsbak er ganske vist inde 1 en industrialiseringsproces, men byen preges tydeligvis stadig af et ideologisk monster, der har rødder $i$ tidiligere perioder. Det giver en vis kontinuitet og resistens, som vanskelliggor, at de kapitalistiske markedsmekanismer far overtaget, og statsintervention spiller endnu kun en perifer rolle (fx. Valutacentralen, som Mads netop ved sin dygtighed kan omga). Det var fra begyndelsen vores tese, at seriens stiliserede $30^{\circ}$ er univers trods alle dens udeladelsessynder bl. a aktiverer langslex hos seerne mod overskuelighed, sammenhang og selvforvaltning. Vi vil prфve kort at se pa, hvad det er for træk 1 vores levede hverdag, som ligger til grund for denne langsel.

Se engang på nøglefiguren Mads og hans forhold til tiden. Han lever $i$ høj grad efter urets tid, den abstrakte kapitalistiske tid. "Tid er penge". Han er den person, der fx. ikke langere har tid til at deltage $i$ missionsstavnerne (episode 15). Han skynder 
sig ogsa på arbejde efter radiomeddelelsen om besatcelsen lepisode 16). Mads markerer en tendens, som accelererer 1 og med kapitalismens fremvakst, og som 1 h $\phi j$ grad er aktuel for seeren, nemIig kvantificering af tid og fysisk opdeling af rummet 1 sferer, opsplitning mellem bopal, arbejde, uddannelsessted, butikker, institutioner 0.5.v. Hvad enten vi har lonarbejde eller ej, gør en stigende samfundsmassiggørelse af hverdagen sig galdende. Vigtigt ex skellet mellem arbejde og fritid, men vi ma ikke glemme at medtanke sammenhengen mellem disse livsområder, hvor fritiden langt hen skal fungere som reproduktionstid, og fx. fysisk eller psykisk udmattelse efter arbejdet krever sin tid for at kunne overvindes. Lefebvre siger:

Das Verhăltnis zwischen Frelzeit und Alltag ist kein einfaches: Einheit und Widerspruche charakterisieren es in gleicher Weise letn dialektische Beziehung also. Man kann es nicht auf eine simple Differenz zwischen "Sonntag" und "Werktag" reduzleren, was bedeuten würde, dass sle einander äusserlich sind. Die Freizeit - wenn wir den Begriff zunächst noch ohne nähere Prufung anwenden - lässt sich von der Arbeitszeit nicht trennen.9)

I forhold tsl en oplevelse af hverdagen som formelt fragmenteret kan TV fungere på flere mader. Det bryder med en ellers opsplittet døgnrytme resten af dagen. Samtidigt reproduceres ofte en lignende opsplitning i enkeltudsendelsex. Fx. benytter "nye" programtyper som shows og quizprogrammer sig af den internaliserede

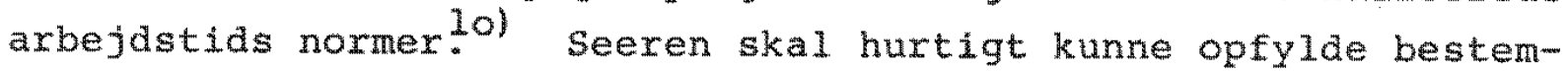
te kxav, fx. 1 form af sporgsmal. Denne fordring er ofte uden indre meningssamenhang og uden rationel begrundelse. vden at beskrive arbejdsprocessen direkte har sådanne programmer skjulte referencer til arbejdet og kan pă den made fungere aisciplinerende. 11)

I modsatning hertil ex Matador et program, som dels i sig selv varer forholdsvis lang tid ( $1 \frac{1}{2}$ time pr. aften), og dels fremstiller et episk, sammenhangende, kontinuert udviklingsforl $b$ som gør, at den i hojere grad modsiger sadvanlig tidsmassig fragmentering $i$ TV-udsendelser. Den etablexer rationelle sammenhange i tid og rum, og den aktiverer historisk erindring on en tid med en kvalitativ anden hverdag og andre livsformer. Det er samme hammel, Morten Korch-filmene trakker pä, og her er vi maske 
freme ved et centralt punkt i den fascination, Matador ud $\phi v e r:$

...mindet om denne produktionsmade der stadig er aktiv 1 manges erinaring. Og der knytter sig mange ideologiske forestillinger til netop denne produktionsmade. (...) set $i$ industriarbejdets perspektiv og ofte endda farvet af barndommens lys, er det ikke svart at forsta landmandslivets fascination. 12)

Den omtalte andring $i$ forholdet til tid og livsrytme synes maske perifer $i$ forholdet til begrebet provins, men den har i hфj grad ogsa noget at gøre med den geografiske provins" omkalfatring i og med den omfattende industrialisering,der sker efter 2 . verdenskrig. Denne tegner sig ogsa i form af urbaniseringstendenser, både 1 form af fysiske andringer 1 landskabet (fx. nye omradetyper som villa-sovebyer) og storre ensartethed 1 alle danskeres livsform - tag udbredelsen af TV som exsempel. Pá den anden side ser vi både $i$ byen og pa landet provins som usamtidig livsform, okonomisk og ideologisk leve videre som langsel efter det 'anderledes" fx. manifesteret $i$ idyllisering af det 'landlige' 'det nare samfund' o.s.v. Her menex vi så, Matador giver et mere sammenhangende ramateriale $t i l$ en progressiv bearbejaning af brudoplevelser og mangler end $f x$. reklamens visuelle løfter om forandring (vel vidende at Matador og reklamer fungerer 1 helt forskellige sammenhange). Til forskel fra disse placerer Matador behovstilfredsstillelsen $i$ en lokalitet og et historisk rum, hvor overskuelighed og sammenhæng ex under nedbrydning/afvikling i samfundet. Og netop denne visualiserede historie giver seeren mulighed for at oparbejde hans/hendes egne brud- og mangeloplevelser (fx. storbyisolationen) til historisk erfaring. 13)

Era denne mere overordnede diskussion vil vi sem det sidste punkt ga over til at beskxive en højst typisk nutidig problemstilling, nemlig konsrolleproblematikken, som indtager en helt central rolle $i$ Matadors tematik. Dette problemfelt lagges via en historisk derealisering tilbage til $30^{\prime}$ erne og $40^{\prime}$ erne. En tematisering af rollex $i$ Matador er naturligt sammenvævet med familierum og familiestruktur. Vi vil redegøre for, hvorledes kvinderoller/ manderoller overvejende tematiseres ind $i$ og op imod familien, som den skildres i Matador. Vi. tager udgangspunkt 1 familierummet. 


\section{KØNSROLLEPROBLEMATTKKEN}

\section{Familierumnet}

Familierumet er af afgorende betydning i Matador. Dette bliver sardeles tydellgt, hvis man tallex antallet af scener optaget 1 hjemnet, dvs. 1 intimssfaren og sammenligner med antallet af optagm elser udendørs og $i$ socialsfaren. Denne opstigningens historie midt $130^{\prime e}$ rnes krise, som Matador skildrex, er nemlig formidet via en familiesynsvinkel.

Hvorfor er dette familierum sa vigtigt i Matador? Vi mener, at vi her skal ind omkring de forhold, der hersker 1 familien idag $i$ begyndelsen af $80^{\prime}$ erne. I modsatning til familiesituationen nu er den familiestruktur, der gengives 1 Matador 1 kke $i$ să h $\phi j$ grad samfundsmassiggjort. Her er ikke tale om funktionstab, onstruturering og desorganisation $i$ form af andringer af de familiale aktiviteter til opgaver for hele samfundet $i$ det omfang, vi kender det 14 . Familiens mere og mere omsiggribende desintegration, fra isar 6o'erne og frem, tilsvarer den kendte vakst 1 den socialstatslige aktionsradius, hvilket vil sige, at staten har overtaget en masse af de funktioner, der traditionelt tilkom familien, bl.a. indenfor udaannelse, opdragelse og forsфrgelse. Vi skal ikke her komme ind pa, hvad denne tendentielle funktionstoming betyder for den interne familiestruktur, men det er den familiestruktur, der er uagangspunktet for den, der ser Matador.

Edvard Shorter siger, at sarligt tre aspekter af familiens tilvarelse idag udvikler sig $i$ retninger, der savner historisk fortilfalde. Han skriver:

Eet af disse aspekter ex den definitive kappen de bånd Iigegyldighed hos ungdommen overfor ramiliens identitet, overfor hvad den star for, der viser sig i forskellige vardisat hos foraldre og born. Et andet aspekt er den nye mangel pa stabilitet 1 parforholdet, der afspejler sig 1 de skyhøje skilsmissetal. Et tredje ex den systematiske nedbrydning af "redeforestilingen" om tilvareIsen 1 kemefamilien, der har varet følgen af en ny kvindefrigorelse: for en stor del af den kvindelige befolkning 1 den vestlige verden har det vist sig, at reden, nar det kommer til stykket, ikke alene er lykken. 16)" 
Disse aspekter er faktisk tematiseret i Matador, og isar de to sidste har en fremskudt placering ift. de problemer, der gribes fat 1. Funktionstomingen tematiseres altså $i$ et vist omfang, og således at mange af de trak, som findes 1 nutidens fanilier, kan genfindes 1 Matador. Dette ex iser tydeligt i skjexnfamilien.

Hvad kan dette sa betyde for seeren, at familien netop ex fremstillet 1 en periode, hvor denne funktionstoming endnu ikke ex să udfoldet? Familiesammenholdet og den familiemytologi, son vi alle er socialiseret til at tro pä pa et eller andet plan, ex 1 Matador fremstillet som stasted med en vigtig emotionel ventilfunktion. Denne funktion er nodvendig i den omvaltning, familierne og individerne udsates for $i$ 30'erne og $40^{\prime}$ erne $i$ form af omlagning af kapitalstrukturen, som Mads skjern er barer af. Denne onlagning far naturligvis stor betydning for det sociale liv, "Tiderne skifter, og sader mildnes", som Jørgen Varnas siger, og ind 1 dette ex det, at kernefamilien fungerer som rede $i$ Matador. Varm og beskyttende $s i k-$ rer den bornene mod den ydre voksenverdens forskellige former for pres, hvilket fx ses i Ingeborgs forhold til Daniel, og den giver mandene et sted, hvor de efter arbejdsdagen med shorters ord kan "s $\phi$ ge tilflugt mod konkurrencens iskolde vinde. "17)

Men dette er kun den ene side af beskrivelsen, nemlig den delvist nostalgiske drom om en anden familie, hvor familien er en rede, og hvor den indeholder tryghed og stabilitet. For samtidig er familien ogsa en uglerede af konflikter og problemer. Den rummer således bade genkendelses- og identifikationsmuligheder for $80^{\prime}$ er-familien og mulighed for nostalgiske dromme.

Der tematiseres saledes nogle brud ift. det slagts-og familiesammenhold, der har varet norm i Korsbak. Der beskrives en udviklingstendens, der gar 1 retning af, at grundlaget for sammenhold bliver snavrere. Fx er der ikke længere søskendesolidaritet mellem Anna og Mads skjern, og skjern- og Varnasbornene kommer sammen pga. personlige sympatier, der vagter tungere end solidariteten med voksengenerationen. Maudes forhold til bornene udgør ogsa en opløsningstendens.

Familien er altså i. Matador beskrevet i al sin dobbelthed, en dob- 
belthed af konflikter og tryghed. Dex oves ikke egentilg kritik mod familien, men den udviser en række modsatninger, der fungerer indenfor samme univers. Mon ikke netop denne modsatningsfylde griber fat i. vores virkelighedserfaringer?

Man skal lagge marke til, hvem det er, der primart skaber og forvalter de direkte og konkrete dagligaagselationer $i$ familien. Det er kvinderne, og dette leder os over $i$ det, der er det centrale tema 1 de sidste 6 episoder, som er meget centreret om konspolitik og specielt omhandler kvindens undertrykkelse og frigørelsesfors $\phi$.

\section{Den kvindelige livssamenhang}

Da familien og hjemmet i Matador valoriseres positivt, og da det primart er kvinderne, der er ansvarlige for dette omrade, er det klart, at det $i$ korsbak er hos dem, de kvalitative strukturer og potentialer ligger. Den kvindelige livssammenheng i husholdning, familie, ven- og bekendtskabskreds er det omrade, som kvinderne entydigt relaterer sig $t 1$, og hvor de er dakket af hverdagsrutiner.

I den politiske $\phi k o n o m i s$ forstand er kvindernes virksomhed på disse omrader uproduktiv, men som Ulrike prokop skriver, implicerer produktionsbegrebet ikke kun produktion af materielle goder, men derimod ogsa altid samtidig produktion af $\frac{1}{1}$ ivssammenhange i form af socialisation, af sociale relationer etc. ") Netop i den kvindelige livssammenheng spiller produktionen af sociale relationer og immaterielle produkter en afgorende rolle, og indenfor denne produktion hax der udviklet sig specifikke kvindelige produktivkrafter. Nogle af disse aspekter tematiseres i Matador og samtidig ogsa kvindernes fors frigørelse fra den underlagte rolle, der blot accepterer de umenneskelige og destrukive sider af manderollen. En rakke storre og mindre opr $\phi x$ mod kvindeundertrykkelsen finder nemlig sted. Hvordan dette er fremstillet, vil vi forsøge at vise $i$ det folgende.

Vi vil sarligt koncentrere os om fire af kvinderne, nemlig Elisabeth og Ingeborg, Maude og Iben. De positive kvindelige vardier eller mangel pä samne, som de sidder inde med, vurderes i Matador meget forskelligt. Bàde Elisabeth og Ingeborg er skildret sardeles posi- 
tivt. De er behovsorienterede og repræsenterer på een og samme gang en traditionel og en ny kvindelighed. Især Elisabeth rumer det fremadpegende aspekt. $P a$ den anden side står Maude og Iben, der er helt andre kvindetyper, som absolut ikke indeholder behovsorienteringselementet. Dette ex det vigtigste modsatningsfelt $i$ den kvindelige Iivssammenhang 1 Matador. De фvrige kvinder kan indplaceres $i$ det same spandingsfelt, men de fire navnte kvinder er dels vigtige personer i Matadoruniverset, og dels udgør de prototyper på måder at administrere kvinderollen på, vi vil derfor kun $i$ ringe omfang komme ind pa de andre kvinder.

Ingeborg og Elisabeth

Ingeborg og Elisabeth ses aldrig fremstillet $i$ en situation, hvor de kan blive opfattet negativt. Dette hanger bl.a. sammen med deres visuelle fremtradelse. Begge barer praktisk taget altid en takkelig og langt mindre pafaldende påkladning end $\mathrm{fx}$ Maude. De to kvinder er $i$ nogen grad materialiserede idealfigurer og ind $i$ dette monster skal ogsa deres moderate selviscenesattelse ses.

Begge kvinder har varet aktive i erhverv, Ingeborg som ekspeditrice i Tøjhuset og Elisabeth som spillelarerinde for borgerskabets born. Hun er nu organist i vor Frue kirke, hvilket ligger helt 1 forlængelse af, at hun, samtidig $\mathrm{m}$ ed at hun fremstilles som relativt emanciperet og kritisk, er barer af den borgerlige hojkultur. Fordi de begge har veret eller ex erhvervsaktive, bliver der fremstillet som langt mere selvstandige og trovardige end Maude og Iben. De har altså en mulighed for at forsørge sig selv, og iser Elisabeth er skildret $s a ̊ j e g-s t a r k$, at hun $i$ nogen grad ex istand til at satte sine behov igennem. Et tydeligt eksempel herpa var fraflytningen fra Varnashjemet.

Ser vi engang på de interfamilare forhold mellem Ingeborg og Mads i scener, der beskriver deres forhold til bornene, udviser de en radikalt forskellig holdning. I episode 17 sidder Mads ved sit skrivebord og laser Berlingske Tidende, mens Ingeborg vanen tro arrangerer en blomsterdekoration. Blandt dagens post er et brev. cer meddeler, at Daniel kan komme i lare hos sands i Hillerød. 
Mads billiger selvfølgelig dette, som han selv har arrangeret, fordi han mener, at drengen skal opdrages til at overtage skjernimperiet, nar tid er. Ingeborg deximod stiller spørgsmasstegn ved dette livsarrangement, fordi det overhovedet ikke indeholder nogle af Daniels lyster og behov, der går på at lare at tegne og male. Mads er ikke til sinds at andre den beslutning, han alene og henover hovedet pa Ingeborg og Daniel hat taget. Han mener, at Daniel i betragtning af storrelsen păhans realeksamen burde vare lykkelig for larepladsen, og han găr sa langt som til at sige, "hvad evner har Daniel egentlig?" Mads legitimerer, at det ex hans beslutning, der bliver gennemfort ved at sige, at "en 17-ars dreng ved ikke, hvad han vil" og ved, at det for ham ex abenbart, at sфnnen skal overtage forretningen efter ham uanset evner og lyst.

I denie og lignende scener, dex omhandlex konflikter ift. bornene, optrader et tableau som gentagelsesstruktur. Uenigheden mellem Mads og Ingeborg er visualiseret ved, at Mads siddex ved sit arbejasbord og. Ingeborg ved sit bord i dagligstuen, således at de sidder forskudt for hinanden, mens de taler sammen. De er filmet, så man ser dem begge på een gang, og Ingeborg ex 1 forgrunden. Det. kan anskueliggores i en tegning:

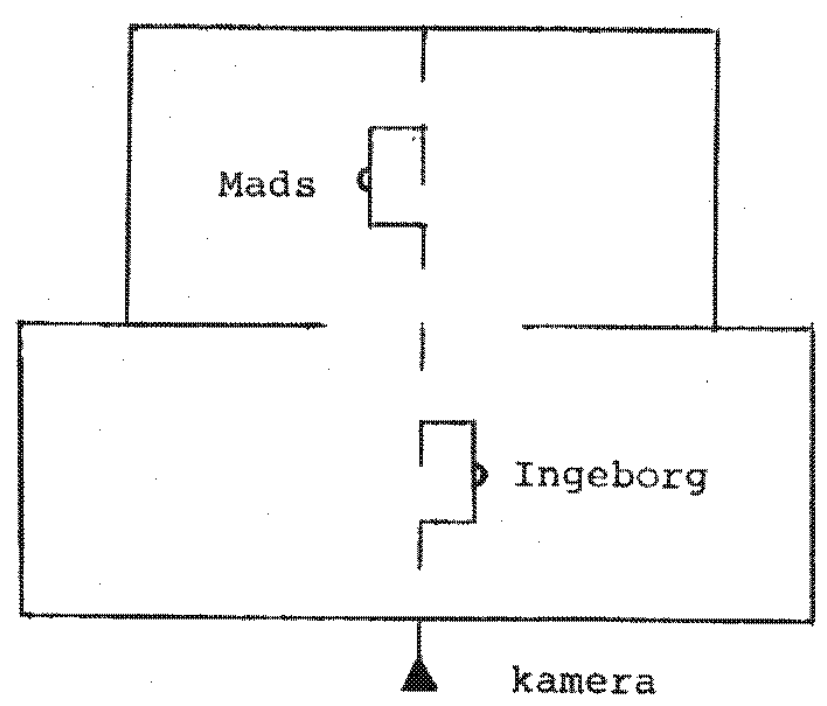

Det, scenen viser noget om, er at Ingeborg 1 høj grad er praget af behovsorientering, og hun viser langt storre interesse for de sociale relationex, end Mads gør. Hun synes ikke, at det er ligegyldigt, tat Daniel har lyst til noget helt andet end det, Mads har arrangeret 
for ham. Der er ogsa en modsatning mellem produktivt og ikke-produktivt arbejde. For Ingeborg er Daniels kxeative evner noget positivt, mens de for Mads' logik er uanvendelige. Ingeborg går langt mere ind for at acceptere folk, som de er i stedet for at lave dem om efter eget forgodtbefindende, sådan som Mads gфr. Hun formidler, som også Elisabeth, rigelig emotionel sikkerhed og varme. Af de kønsrollestereotyper, som traditionelt tilskrives kvinder, har savel Ingeborg som Elisabeth kun påtegninger i den positive side. De besidder sensibilitet, intuition og vigtigst evnen til behovsorienteret kommunikation.

Ingeborgs reprasentative funktion er serdeles tydeligt visuelt fremstillet. Hun ses 1 praktisk taget hver scene med enten en frugtskal. eller blomsteranretning, der begge signalerer den astetiske fremstilling, der nu er blevet en af Ingeborgs vasentligste funktioner. Hun er ansvarlig for atmosfaren, hyggen, madplanen, indretning, egen selvfremstiling via frisure og toj, men ex ingenlunde tilfreds med denne rolletildeling og фnsker sig tilbage til forretningen igen. Fx siger hun $i$ episode 14 til Gudrun, at "min mand har en eller anden ide om, at jeg skal sidde til stads. Det forbyde Gud". Den udviklingsproces, som Ingeborg gennemlфber, bevager sig i retning af den borgerlige livsform, som Maude reprasenterer.

Ingeborgs behov for ikke kun at vare degraderet til den reprasentative funktion er visualiseret pă den măde, at hun flere gange, nar Mads 'har forretninger' hjeme, forst charmerer og snakker med forretningsforbindelsen og viser ham ind. Senere går hun lidt foran døren ind til Mads" arbejasvarelse, og sa - helt konkret skydes skydedøren $i$ for næsen af hende, og hun er i bogstaveligste forstand lukket ude fra det betydningsfulde arbejde. Der zoomes ind på hende, og hun ser opgivende og skuffet ud.

I en del forhold er Ingeborg umyndiggjort. Da hun og Mads skal overtage det store købmandshus, ex Ingeborg højligen forbavset, og hun siger bl.a.: "Ja, lad os gă ind og kikke:" og han udsteder yderligere imperativer som $\mathrm{fx}$ "Kom herhen:" Til Ingeborgs tovende indvendinger, der går pa, at hun hellere vil blive boende over forretningen, siger Mads, "Jamen, det kan du ikke. De to huse i 
Algade skal rives ned." altimens han forventningsfuldt ser på hende, der står med ryggen til ham. Hun vender faktisk ryggen til hans ekspansionstrang, og scenen illustrexer, hvordan han tager beslutningerne hen over hovedet på hende og slet ikke tager hensyn til hendes behov.

Men trods Mads' beslutningsdominans er Ingeborg ikke $i$ et og alt underlagt hans "regler" for handling og adfard. Hun har en selvstandig identitet trods Mads" fors $\phi g$ pa at hindre hendes autonomi. Dette viser sig $i$, at hun handler selvstandigt ift. urimeligheder, som Mads begar fx overfor Arnold og Agnete. Hun plastererer også ustandseligt på de utidige indgreb, som Mads byder bornene. Det, at Mads' pengelogik, som 1 socialsfaren er en sardeles effektiv størrelse, på uanstændig vis tranger ind i kernefamilien, som egentlig ogsa if lge Mads" selvforstaelse skulle opfylde redefunktionen ("Ingen skal komme med deres tro og bringe ufred 1 mit hus", som han siger 1 episode 15), opfattes af Ingeborg overordentigt negativt. Det ses, at Ingeborgs adferd er langt mere ekspressiv, 1 kkeinstrumentel og ikke rettet mod virkeliggorelsen af fremtidige mål, sådan som Mads" er.

Via Ingeborgs evne til at leve sig ind $i$ andres behov, det.som Prokop kalder den kvindelige imaginationsevne ${ }^{19}$ " fremtrader Mads" adfard dobbelt grel. Hendes væremade bliver en direkte kritik af Mads" manderolle og mere overoranet af den rationelt- $\phi$ konomiske logik, som han reprasenterer. Men at dette bliver til en modsatningsfyldt kritik, vil vi vende tilbage til.

Ogsa Elisabeth fremstilles via sin altid behovsrelaterede handlen som en positiv identifikationsfigur. I alle henseender er Elisabeth den gode og behovsopfyldende kvinde ift, hele varnasfamilien, kristen og Dr. Hansen, og hun ex altid parat til at affyre sma solidam risk-kritiske stikpiller, som satter forholdene i proportion. Fx korrigerer hun den fuldstandigt hamningslфse ubetænksomhed og mangel pa indsigt, som Maude lagger for dagen $i$ en udtalelse som "Det burde vare lov, at alle skulle tage til paris mindst hvert femte ar" i episode 13. Elisabeth siger ganske enkelt, at det skulle hun forelagge stauning, for arbejderne vil sikkert synes godt om for- 
slaget.

Elisabeth angriber den stivnede borgerlige kultur, som i egen selvforstålse oplever det som såre naturligt mad de mange klasseprivilegier. Elisabeth tager afstand fra de 1 hendes $\phi j n e$ umoralske forhold, og hun sidder iфvrigt inde med flere af de trek, som karakteriserer kulturradikalismen $130^{\prime} e^{20}$. Hun er praget af den kvindelige imaginationsevne, kulturradikal humanisme med sans for verdens uretfardighed og hun ex en kvinde, der lever alene, selvom Kristen med nogen sandsynlighed venter $i$ kulissen pá at optage den bruate forbindelse. Men hvad ser vi sa? - En stolt, fri og glad kvinde med en massse overskud? Nej- ingenlunde: Vi. ser en fortsat mere og mere sig-selv-ynkende kvinde, en rigtig skyggetante, der til stadighed gor alle de udadlelige ting og ex lige betydningsfuld for de mennesker, hun omgas - indirekte onsker man næsten, at hun forfaldt til en rigtig egoistisk bommert. Selv siger hun, at hun altid ex den samme, at hun ex ved at blive et trist tilfalde, og at det er hun oprigtigt trat af at vare. For hende synes der ikke at va re megen grund til at blive 1 Korsbek, men alle stotter hende $i$ at blive der. Hun er frustreret og utilfreds med sin tilvarelse, selvom hun ex den kvinde, der i storst omfang er subjekt for sit $1 \mathrm{iv}$. Elisabeth er finansielt og emotionelt uafhangig, og det er måske det siaste, der er problemet. Den situation, hun er havnet i, skyldes, at hun har handlet "forkert". Idet kristen er blevet opgivet, har Ioyaliteten overfor Varnasfamilien vægtet tungere end egne følelser. Her ligger hunden begravet. Godt nok er det 1 det matadorske univers udmarket at vare en kulturradikal humanistisk kvindefrigjort kvinde, men hvad er det altsammen værd, når man ikke bliver gift? Det ex det budskab, der bringes igennem. Pa trods af den agm teskabskritik, der formidles $i$ Matador, er der altsa også noget andet på færde. Hvis man vil være alenekvinde eller bliver det af skabnens unadige gunst, ma man sxtte sin livsforventning lavt.

Maude og Iben

Maude blev $i$ de forste 12 episoder skildret som en "hypersensibel og uselvstandig overklassekvinde, der ganske vist ex pakket ind $i$ vat og uselvstandiggjort via sit miljo"2l), og hendes overbeskyt- 
tede liv giver hende kun en katastrofalt ringe indsigt i, hvordan livet udspiller sig udenfor det borgerlige familierum. I de afsnit, vi analyserer, gives der dog positive brud 1 Maudes ilv.

Noget af "fejlen" hos Maude og de kønsrollestereotyper, man genfinder hos hende, er, at hun praktisk taget udelukkende har karakteristika i den 'dårige' skala. Normalt tilskrives kvinde sensibilitet og intuition, som netop ex de egenskaber, son Elisabeth og Ingeborg besidder 1 rigt mäl. På den anden side tillægges kvinder ogsa hysteri, lunefulahed, inkonsistens, behov for at behage, passivitet og jegsavghed, og den selvcentrerede Maude befinder sig herindenfor.

Ingen forventer udfra hendes klasseposition, at hun skal tage del 1 de særligt repetetive dele af husarbejdet, ellex at hun skal passe sine børn selv. Men hun burde vare interesseret 1 dem. En af de mest udbredte kvindemyter, nemig myten om den sarilge mor-barn-relation, er et af de aspekter som Maude ikke lever op til. Den forstålse og indføling, som her er nфdvendig, sidder hun ganske enkelt ikke inde med. I det hele taget har hun ikke nogen reel funktion $i$ huset, idet den eneste forpligtelse, hun har vdover egen selvfremstiling, er at vare der for Hans christian.

Imidlertid formulerede Maude specielt $i$ de forste 12 episoder en diffus stadigt tilbagevendende indirekte kritik af sine livsforhold ved sa ofte at trakke sig tilbage til sovegemakkerne. Hun fremstilles altså, som om hun selv føler den udhuling og tomhed, som er en del af den rolle, der er blevet hende til del. Men den kritik bliver aldrig taget alvorligt af nogen, og Laura kalder det komedie. Men den afbojning ift. konflikter viser en afmagt overfor rollen og situationen, og hun artikulerer ubehag og lidelse ved undertrykkelsen og uudvikletheden af de produktive momenter $i$ adfard og exfaring. Dette giver sig udtryk 1 bestemte ritualer 1 dagligdagsadfærden, hysterisk renlighed og selvoptagethed. De ytringer og adferdsmader, som Maude giver udtryk for, er regressive og kompensatoriske, men de indeholder kritik og protestmomenter. og hvordan behandles forholdet sa? Maude er primaxt fremstillet som et hysterisk overklasseløg, son undviger virkeligheden ved fx at $g a$ $i$ seng uden at det vises, hvorfor hun gør det. 
Maudefiguren ex en yderst vigtig figur, fordi man gennem den far gennemspillet en rakke ubehagelige sider af følelsesregistret. Fordi Maude er så entydigt egoistisk og ikke-indfølende, er hun en person, man let kan tage afstand fra, mens der samtidigt pirkes til en del dårlige sider, som man selvfolgelig ikke kan have 1 det omfang, som Maude har. Hun kan saledes blive genstand for projektion.

En helt anden kvindetype er Iben. Hos de fleste andre kvinder er det sadan, at deres samfundsmessige skabne fremfor alt er bundet til den rolle, som de udøver som mor, hustru og husmor. Her onsker Iben kun at have hustrurollen, som hun ikke vil lagge ind under det normative felt, der hedder rolledeling og magtforskel: Hendes generelle protestholdning over for den kvinderolle, Kristen har tiltankt hende, og hendes indgăen $i$ alle mulige sammenhange med veninden Jenny, sker pa bekostning af udovelsen af de funktioner, hun 'skulle' have udfort 1 hjemet. Det er det, son skildres som 'galt'. Noget, som også fremgar af følgende replikskifte fra episode 15:

Kristen: "...sä kunne du maske lare noget af dem. Det er ubegribeligt, hvad du licte pa den Hausfrau-skole 1 Tyskland."

Iben : "Det kunne jo netop vare, at jeg larte, at jeg ikke ville vare.Hausfra."

Kristen: "Jamen hvorfor giftede dú dig sa?"

Iben: :Jeg giftede mig med dig, ikke bankbestyrelsen og en botte brun sabe."

Kristen: "Vi har jo hver vore opgaver. Jeg har banken og du har det her. Hvad er det egentlig du vil?"

Iben : "Have en rideskole. Det kan jeg. Men det er selvfфlgelig ikke fint nok at have en kone, der er berider. Det ville vare finere, hvis jeg sad og hamrede 1 orglet 1 Vor Frue, sadan som den gamle moster du altid rendte efter."

Det, scenen viser noget om, er, at der for kristen er en explicit norm, der gar ud pă, at han nok skal forsprge Iben og til gengald regner med en rimelig varetagelse af husholdningen. Men Iben er en kvindetype, der peger frem mod nutiden. Hun ex erhvervsorienteret og onsker sig oven $i$ købet et traditionelt mandligt erhvervsmal i form af en rideskole. Hun går imod den opspaltning i konsspecifikke omrader, som kristen onsker, og har ingen ambitioner om at lare at "f: blomster til at stritte ud til alle sider" (episode 14), sådan som Ingeborg kan det. Hun vil ikke indtage den reprasentative funktion, som de andre kvinder patager sig, og formulerer explicit et onske on autonomi. Dermed vil hun hellex ikke lare no- 
get af de "urgamle" kvinders normer, sădan som Kristen foreslår hende det.

Iben besidder heller ikke syndromet dameagtighed, velplejethed, derimod ses hun ofte $i$ ridedragt, dvs. benklader, skjorte og jakke, hvilket ikke er den mest kvindelige pakkladning, man kan tanke sig. I episode 18 ses hun arekte sjusket med uredt har og tøjet 1 uorden. Hun har ogsa en langt mere kropsligt-sanselig holdning end de andre kvinder. Hun găr ikke damet, men som en kvinde, der ved, hvad hun ikke vil.

Hun accepterer ikke Kristens beslutningsmagt og griber selv ind og omfordeler den beslutningskompetance, som Kristen mener, at han har monopol på. I et af deres utallige sammenstød siger han som sidste trumf, da hun har glemt at bringe hans festskjorte til vask, at hun skal bede Yrsa bringe hans mad hen i banken. For ham er det nemlig legitimt at udstede den slags ordrer, som inden for hans univers skulle lukke munden pa hende. Hun opfylder nemlig ikke sine forpligtelser. Iben svarer vredt: "Gør det selv, jeg gar i ridehuset" og så går hun, smakkende med døren. En lignende satning har mange kvinder sikkert affyret mod deres agtemand $i$ det frig $\not-$ relses tiår, vi just har veret igennem, og pà den led vil iben kunne fungere som en identifikationsfigur, nemlig som den, der formidlex kritik af blot-og-bar-husmor eksistensen. Men beskrive1sen af hende kammer over og bliver ikke sarlig positiv. Dette udvirkes bl.a. af det kvindefallesskab, hun har med Jenny, der er fremstillet som et 1 losluppent fruentimmer med sans for utroskabens herligheder.

Opsamiende om den kvindelige livssammenhæng.

De kvindelige produktivkrafter og isar hehovsorienteringen, som i Matador valoriseres positivt, far ogsa nogle negative konsekvenser. Her vil det vare relevant at se pa hvilke oprorsformer, kvinderne tager 1 anvendelse. Hvilke muligheder er der overhovedet for opror og modstand i Korsbak-universet?

Ingeborgs modstand mod den $\phi$ konomiske logik, som Mads repræsente- 
rer, bliver inden for de $i$ forvejen formulerede rammer. Konflikten mellem dem udspilles på det grundlag, at udgangen på den alarig kan føre til familiens opløsning. For Elisabeths vedkommende er der tale om, at den behovsorientering, hun sidder inde med, komner til at sta $i$ vejen for reel emancipation. Nar fx Maude, Hans chr. og Regitze mener, at de har brug for hende 1 Korsbak bliver hun der og anvender ikke sine potentialer til den forandring, hun selv onsker. Elisabeth er meget kritisk overfor egteskabet, om hvilket hun $i$ bitre vendinger siger til Kristen: "Det larte vi jo var lykken, og hvad ex det sá for de fleste?" (episode 18). Den relative autonomi, hun har, skildres ikke positivt, og det gør agteskaberne heller ikke. Der bliver salledes tale om, at man skal valge mellem to onder, og Elisabeths opror ender foreløbigt i en skyggetantetilverelse.

Ibens oprox er diffust. Hun har ikke lyst til at indorane sig under zgteskabets mere faste ramer, og fremfor alt har hun ingen ambitioner on at iudtage husmoderrollen. Men oproret kanaliseres over $i$ det dekadente. Det skilares som alt for lystbetonet til egentlig at kunne blive grobund for kvalitativ forandring af hendes livssituation.

\section{Manderoller}

overfor disse kvindelige positioner har vi de mandlige Herindenfor fungerer Mads skjern $i$ et eller andet omfang som malestok for, hvordan de andre mand opfattes.

Først og fremmest inkarnerer Mads den okonomiske rationalitet. Han er historien og myten om $\phi$ konomisk succes. Han reprasenterer for de mennesker, der aspirerer til at blive borgerskab, og vasentligere for alle andre myten om, at den sociale opstigning er mulig. Dette understreges af de opstignings-parallelforl $\phi$, der beskrives 1 Agnes' og Arnolds personer. De kvaliteter, der udgør basis for hans effektivitet, ex det, vi med steffen Kieselberg kan kalde "karakter" og "rationalitet" hvor

...karaktexbegrebet dakker over en generel disciplinering af driftsivet, således at det $i$ et og alt mariretes efter vardirationaliteten og resulterer $i$ den 'selvkon- 
trol', som er vandnarket på et rationelt vasen. 22)

Dvs. at dritterne ikke negeres men underlagges instrumentelle formal. Udgangspunktet for Kiselberg er, at overgangen til kapitalistisk produktionsmade medforer en stramning af de samfundsmassige krav on jeg-styrke, saledes at den individuelle jeg-styrke under de morede produktionsforhold i højere grad bliver lig med indre tvang, avs, selvtvang og over(selv)kontrolleret undertrykkelse af spontan ariftsimpuls.

Mads" karakter kan man vasensbesteme med de traditionelle smăborgerdyder som sparsonmelighed, arbejdsomhed og nutidsforsagelse. Dette nodvendiggør udskydelse af tilfredsstillelse af de spontane arifter til fordel for fremtidig gevinst. For Mads drejer det sig ikke om ydre tvang, sadan som det gor for Arnold. For Mads er der nemlig tale om meningsfuld selvtvang $i$ det omfang, han har erkendt forholdet som betingelsen for materiel succes.

Man kan blive fascineret af Mads, fordi han reprasenterer det magtfulde, det at tingene kan lade sig gore. Og et andet aspekt, der vil kunne udvirke en positiv holdning til Mads er, at han, selvom hans destruktive sider slar negativt ind i familierumet, beskytter familien, som vi ved er noget positivt i Matadors univers. Det er nemlig vigtigt, at han pa een og same gang destruerer og beskytter familien.

Mads henter nasten udelukkende sine anvisningsstrukturer og normer fra de reproduktive funktioner i familiesammenhangen og specielt. overfor sit eget folelsesmessige potentiale. Der formidles et indtryk af, at han ex glad for Ingeborg, og $\mathrm{fx}$ siger han til hende "Vi har da haft det godt, ikke?" og hun svarer "Jo", og man har pa fornemmelsen, at penge ikke alene er lokkemad for hans begar. Han vil nemlig også gerne gøre Ingeborg glad og give hende en glade.

Børnene holder han ogsa af, men det pä en relativt magtrelateret facon, som ikke anerkender forskellighed, hvilket er tydeligt ved Ellens bryllup og ved Mads' valg af Daniels Eremtid. 
En anden mandetype er Røde. Han ex son ogsa kresten en mere nutiaig mandefigur, der i langt hojere grad ex orienteret mod de store perspektiver, mens de små som egentilg er til at Ealde over, ikke ofres megen opmerksomhed. Det er klart, at Røde politisk udtrykker en vis dynamik, men han er ikke istand til at administrere de to perspektiver, sa de kommer til at stg i et rimeligt forhold til hinanden. Hans overskriden af granser er direkte proportional med det, han 'mister' i familierumet 1 forhold til Agnes og bornene. Hans fremtoning konstratexes med lovemoderen Agnes, og derved bliver han beskrevet som uansvarlig, umoden og egoistisk. Hans manderolle er klart beskrevet som negativ og ma 1 et vist omgang kunne fungere som en 'påmindelse' til mange nutidige mand.

Alt $i$ alt ex mandene fremstillet som overvejende instrumentelle. De kan se de store perspektiver men mister samtidig kontakten med de sma. Heroverfor er kvinderne affektivt orienteret. Mandenes prioritering bliver i Matador udsat for kritik, men til gengald kan kvinderne ikke se de store perspektiver og handler nasten udelukkende udfra behovsorienteringen og nu'et. De fastholdes derved i den situation, som de kxitiserer, og behovsorienteringen indeholder således også noget regressivt. Kvinderne sørger for, at den $\phi$ konomiske rationalitets hensynslфshed og de negative aspekter af manderollen ikke kommer til at fungere fuldt ud. Via det, at det er kvinderne, der er kritikkens instanser og samtidig løser problemerne $i$ de selvsamme forhold, der kritiseres, opretholdes netop en balance $i$ et modsatningsfyldt univers.

Her vender vi sa tilbage til vores udgangspunkt, nemig vor tese om det dobbelte brugsvardiaspekt, idet der netop er tale on en balance eller harmonisering af konfliktfeltet mellem de mandiige og de kvindelige positioner. Men samtidig afdakkes dette konfliktfelt, og vi ser en rakke mulige reaktionsmonstre gennemsplilet som muligheder, der kan fungere ind $i$ en fortolkning af det egne liv og de kønspolitiske udviklinger og afviklinger, man dex gennemlever. En række konflikter ift. kønspolitik stăr uforløst hen og kan blive anstødssten og grobund for en produktiv beskxftigen sig med problemerne. 


\section{SAMMENEATNING}

Forst afdakkedevi hovedstruktureringsprincippet $i$ form af konfliktharmoniforløbene. Dernast koncentrerede vi os om to delaspekter, nemlig diskussionen om provinsbegrebet - der ogsåknyttes til seerens mere konkrete mangeloplevelser - og kønsrolleproblematikken, som mest progressivt tematiserer undertrykkelsen og oproret. Den. far direkte serien til at rakke ud over sit eget univers. Det var fra starten vores tese, at Matador lagger op til en dobbelt behovsopfyldelse, og det ser ud som om de tre analysedele viser forskellig vægtning af disse. Konflikt-harmoniforlobet peger i de forste 18 afsnit hen mod det første behov, nemlig trangen til harmonisering (forstaet som psykisk proces hos seeren). provinssynsvinklen peger på begge muligheder, nemlig regression og overskridelse. Konsrolletemaet lagger mere direkte op til en produktiv konfliktbearbejdning.

Spprgsmålet om familie og kønsroller befinder sig i et spendingsfelt mellem et billede af mindre opsplittede sammenhange og samtidig opløsningstendenser og konflikter. Familien fungerer bade som rede og uglerede. Det er centralt $i$ forhold til vores tese om den dobbelte brugsvardi, at de kvindelige potentialer og oprorsmuligheder ex forlagt til en provinsby i 30'erne, hvor hojst patrangende kønspolitiske problemer $i$ det egne liv kan bearbejdes på en behagelig tidsmassig afstand. Problemerne fastholdes $i$ et spandingsfelt mellem narhed og afstand og bliver til en vis grad ufarlige at forholde sig til. Identifikationen ex mulig på mange niveauer, men bliver ikke problematisk at indlade sig på p.g.a. derealisationen. Den behagelige risikofrihed råder tilsyneladende:

\section{PERSPEKTIVERING}

Den dobbelte brugsvardi og de dobbelte behov

Det underholdende/harmoniserende og det oplysende/problembelysende findes naturligvis ogsa som brugsverdier $i$ andre uasendelsestyper, men sjaldent i sa klar og veludviklet en kombination. Kun Kanal 22 (som helhed betragtet) har en lignende, omend ikke samme 
dobbelthed, som pavist af Peter Larsen og Exik Nordahl Svendsen 1 artiklen: "Kanal 22 som columbusæg", hvor de, sammenfatter analysen med følgende:

Vi forsøgte her at bestemme de trak, der har givet det (Kanal 22, vores indskud) dets popularitet, - focuseringen på den personlige erfaring, der bevirker at programmet bade opleves underholdende og seriøst. 23)

Vi ved, at de to vidt forskellige programtyper har varet et par af DR"s mere solide succeser, bade malt 1 seertal, bredde $i$ seerprofil og - tor vi påsta - 1 oplevelsesintensitet. Det er niarliggende at soge forklaringen påsuccesen i det, der er falles for de to udsendelser, nemlig kombinationen af underholdende og erfaringsoparbejdende brugsvardier, forstäet som en kombination af lige vigtige brugsverdier. Dvs. at de underholdende elementer ikke kun tjener som glasur, der skal fa den seriøse/bitre pille til at skride ned. Det er vores pastand, at det underholdende og seriфse drager gensidig fordel af at optrade integreret $i$ samme tekst. og at de imødekommer dobbelte behov hos seeren. Bade behov for tryghed, harmoni og overskuelighed i tilvarelsen, og behov for erfaringsoparbejdelse, фget tilværelses- og samfundsforståelse. Vi vil argumentere for păstanden ved at beskrive brugssituationen, nar de to brugsvardier optrader hver for sig.

Først situationen, hvori seriøse programmer forbruges. Modtagelsen af seriøse programmer - fiktive og ikke-fiktive - er grun- . digt behandlet hos adskillige medieteoretikere. Synspunkterne spander:

- fra Adorne og Horkheimers pessimistiske syn pa seriøse teksters gennemslagskraft, sammenlignet med rent underholdende/kulturindustrielle tekster:

Visse medieteoretikere knyttex an til tesen om den bevidste illusionsdannelse. Isar Adorno og Horkheimer viderefører $i$ deres medieteorier lignende synspunkter. De betragter konsumeringen af kulturindustriprodukterne som en bevidst fortrangning. Individerne hopper ikke alene på bedraget, de onsker ogsă bedraget, som de selv gennemskuex. 24)

- til Negt og.Kluges mere optimistiske krav on samtidighed i problembelysning og handlingsanvisning, som en måde på at overvinde modtagelsesvægringen på. 
Det dreier sig her om problemet fjernsynsrealisme. Den rene avbildning af virkeligheten, $\mathrm{fx}$ dokumentasjon av fremmedgjorte arbelasprocesser, støter mot det faktum at folk bare forbinder lyst med tilegnelsen av slik erfaring, hvis de vet hvordan de aktivt kan andre de plagsomme forholdene. Først ut fra en sik handlingsmulighet kan folks interesse for realisme rekrutteres. 25)

Som påvist findes denne handlingsanvisning i Matadors kvindetema hvis udforming altsa sikrer, at modtagelsen af temaets budskab ikke bliver for pinefuld. Dertil kommer, at kombinationen med hovedforl $\phi$ bets harmoniseringer og provinsmiljøets overskuelighed ved sin behovsopfyldelse fremmer trygheden mellem medie og modtager, der fremkommer en tryg og afslappet brugssituation. Denne brugssituation er forudsatning for, at seeren ikke alene finder det overkommeligt, men er ogsa en forudsatning for, at seeren har lyst til at modtage de problembelysende dele af teksten.

Dette er vel en forholdsvis anerkendt virkning, men den bevager sig egentlig ikke ud over "glasur-teorien' og forklarer ikke, hvorfor Matadors brugsverdikombination skulle være bedre end rent underholdende tekstex, der jo ogsa giver en tryg brugssituation. Eller med andre ord, hvordan drager de harmoniserende dele af teksten fordel af at vare integreret med de problembelysende dele? Med dette sporgsmal vender vi os til den situation, hvori de rent underholdende tekster forbruges. Vi vil indkredse brugssituationen med et citat fra en sang om ugebladsforbrug, "show", af rockgruppen skilfinger:

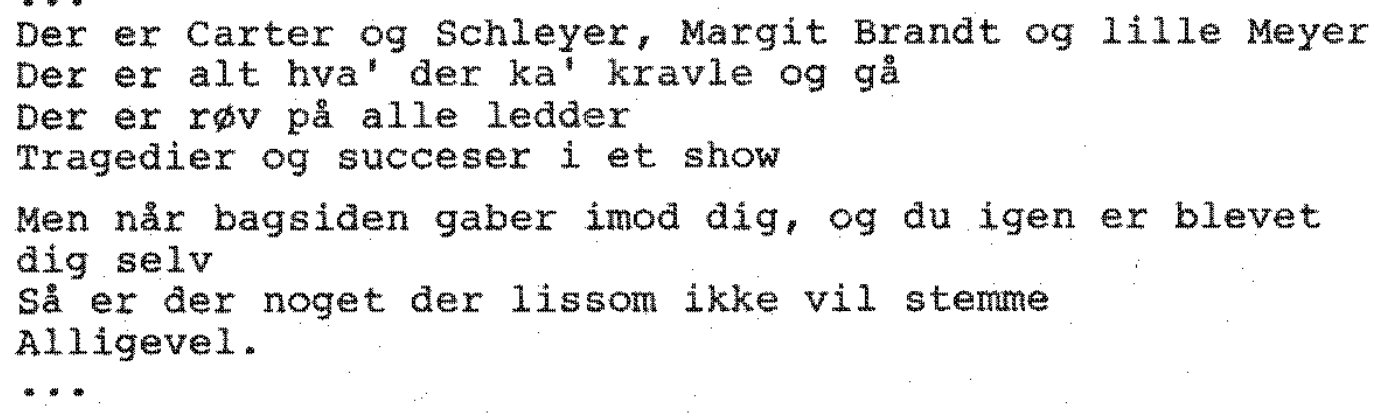

Det rene underholaningsforbrug tilfredsstiller nok nogle behov, men afsatter samtidig en mangelerfaring. Hvis dette ogsa gør sig gxldende ved forbrug af rent underholdende TV-udsendelser, tyder det pa., at man i brugssituationen fár opfyldt sine underholdningsbehov samtidigt med, at man har en nagende medbevidsthed om, at 
det netop er denne passive slaen-tiden-injel og en problemflugt, som man ex 1 gang med. (Laseren kan selv afprove pastanden naste gang han/hun har hangt foran skarmen fra tegnefilmene til godnatbilledet en lordag aften:) Hvis denne antagelse holder stik, galder det videre, at orkeslosheden, on ikke forsvinder, sa dog fortoner sig, nấr de underholdende dele kombineres med indsigtsgivende dele. Ikke alene fordi det seriøse kan tjene som legitimering af forbruget, men ogsa fordi teksten faktisk tilfredsstiller erkendelsesbehov, som ren underholdning ikke kan tilfredsstille. Behov som man ellers ma søge at dakke ved hjalp af andre nediex. eller som forbliver udakkede, fordi de fremtrader i en form, der gør erkendelsen for pinefuld. Konkluderende kan vi altsà sige, at det er Matadors specielle styrke at den med sin brugsvardikombination imødekommer dette dobbelte behov for harmoni og erkendelse, og Matador skaber dermed en brugssituation, som seeren hverken oplever som pinefuld ellex orkeslфs.

\section{NOTER}

1) Eksempler pa denne provinsforskning kan ses i Kritik 56, som er temanumer om provins. Jf. Bang m.fl. i litteraturlisten.

2) Reyher, 1975 s.331. "..arthistorisk minnesrest."

3) Arentoft, $1977,5.9$.

4) ibid. 5.8 .

5) Falk, 1978, s.11.

6) Bang m.fl., 1981, s.30.

7) Zerlang, 1976, s.47f.

8) Bang $\mathrm{m} . \mathrm{fl}, 1981, \mathrm{s.22ff.}$

9) Lefebvre, $1977,5.38$.

1o) Krovoza, 1978 .

11) Buselmeier, 1974, s.191.

12) Dan Nissen, 1980, $s .396$.

13) Jan Mølgåd kommer 1 sin artikel "Tilbage til den indre hjemstavn - serier og serieforbrug" $i$ Kritik 56 ind pa denne personlige dimension.

14) Jf. fx Harriet Holter m.fl.: Familien $i$ klassesamfunnet.

15) Edvard Shorter, 1979, 5.291 .

16) Vore understregninger.

17) Edvard shorter, op.cit., s.302. 
18) U1rike Prokop, 1978, s.66.

19) ibid. s.71ff.

20) Jf. fx Ellen Krog m.fl.. Indledning til antologi af nordisk 11tteratur, ba.9, s.32ff.

21) Jørgen stigel: "Matador. 30'erne som mere end underholdning." in underholdning 1 TV, $\$ .61$.

22) Kieselberg. 1979 .

23) Underholaning i TV, 1981, s.103.

24) Fausing, 1977, s.38.

25) Negt m.t1., 1974, s.129. 
RESUME AF EPISODERNE $13-18$

Episode 13. "Et nyt 1iv" (1937)

Der varsles nye tider i Korsbak. Bankdirektoren kans Christian Varnes og Maude ex vendt hjem fra en rejse til paris. De har fiet stablisseret agteskabet efter Hans Christians affere med bankassistent vila, der fik en lllegal abort, da hun var blevet gravid med ham. varnasserne holder en grandios fest for deres "unge" bekendte, deriblandt nye vennex, de har truffet på rejsen. Den noget vulgare sagforex skjold Hansen deltager ogsa 1 festlighederne, da han har fäet en stark position 1 Korsbak Bank. Ved festen serveres bl.a. cocktails og artiskokker, bordpynten er 1 tricolorens farver, og dex danses til jazzmusk fra en ny rejsegramofon; alt dette er traditionsbrydende 1 forhold til tidigere fester, og den ender 1 stor løssluppenhed. Maude Varnæs viser sig at vere blevet gravid på rejsen, $\propto$ I forbindelse med graviditeten falr hun et usadvanligt psykisk overskud. Hun bliver mindre pylret og găr ikke langere $i$ seng să snart, noget gât hende pă, heller ikke, da Hans Christian fortzller, at skjold Hansen vil kobe en grund fra deres have for at bygge et garageanizg der. Imiliertid nogter hun datteren Regitze at beholde en hund, son denne hax făet, og både Regitze og broderen vlrich stiller sig meget fjendtligt an over for Maude. Maude forsoger bl.a. at finde trost hos sin ugifte sфster, Elisabeth Fris, der imidlertid har sit at slas med. Efter at hendes kareste, Kristen skjern, har giftet sig med skjold Hansens datter Iben, pattankex Elisabeth at forlade byen. Hun vil rejse til kobenhavn for at passe sin mor. Hendes ven, dr. Hansen, råder hende fra det og opfordrer hende $i$ stedet til at spge et organistembede 1 Korsbak. Eun far embedet trods menighedsrådsformanden, Mads skjerns uvilje, idet hans. kone overtalex ham, Maude føder en datter, son făr navnet Helle, men konflikten mellem Maude $\mathrm{og}$ de to store born ex abenlys. Imens bygger manufakturhandlex Mads Skjern nyt magasin 1 tre etagex, og uden sin kone, Ingeborgs, yidende og billigelse kpber han en stor herskabsvilla uden for Rorsbak, hvor familien flytter ud, og hun mă modvilligt opgive sit arbejde 1 forretningen. Episode 14. "Brikkerne" (Efterar 1939 til forat 1939)

Mads Skjern regerer sit imperium. Han opretter fillaler og kober sig ind 1 Gräs kladefabrikker 1 Kobenhavn. Familien Gra, der selv opholder sig 1 schwelz, har ansat Jørgen Varnos son administrator. Men da Mads skjern făr plads 1 bestyrelsen, overtager han mere ellex mindre ledelsen, sâ Jorgen Varnas 1 praksis degraderes til lonarbejder for ham, og da han uden Mads" tilladelse holder forlanget Juleferle, ramer Mads ham ongäende pa lonnen. Hans Chr. Varnas tager ud til Mads og beder ham frigøre Jørgen fra sin bundethed, sâ han ogsa kan ar- 
bejde som rădgiver i korsbak Bank og derved supplere sin forringede indtagt. Dette Indviliger Mads $i$. Ogsa Ingeborg foler sig trangt, da hun nu ex henvist til de reprasentative funktioner 1 hjemmet, men hun tagex affare over for Mads, da han gøx den unge ekspedient, Arnold vinter, til flliabestyrex 1 slagelse. Arnold har nemlig gjort sin forlovede Agnete gravid, men Indirekte foranlediget af Mads slär han håden af hende, da han fár den nye stilling. Ingeborg sørger for, at Agnete alligevel flytter med ham, og de bliver gift. Mads far afskediget den gamle larex Andersen fra den private skole, da han forf $\phi 1$ ger Mads og Ingeborgs $s \phi n$, Daniel. Kristen og Ibens egteskab gåx dårligt. Iben vil være berider og nagter kategorisk at varetage de huslige opgaver 1 hjemmet, men tager 1 stedet afsted med en veninde til ridning eller til bal, alt sammen til kristens store fortrydelse.

Eplsode 15. "At tanke og tro" (Efterăr 1939)

Selv of de morke kxigsskyer hanger tungt over Danmark, er det ikke de storpolitiske begivenhedex, dex bekymrer korsbaks beboere. Ingeborg og Mads Skjerns søn Daniel skal konfirmeres og fejres med en stor familiefest. I den anledning holder en ny, markant person sit indtog 1 Korsbak. Det er Mads og Kristen Skjerns søster Anna. I modstning t11 sine brøare hax faster Anna ikke frigjort sig fra sin barndoms missionske og asketiske miljo, og hun har svert ved at god-

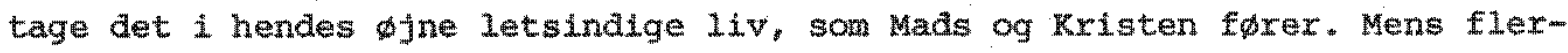
tallet i Korsbak lkke kan overskue, hvad det ex, der skex ude 1 Europa, folger den kommistiske jernbanearbejder Laurltz Jensen, kaldet Rфde, aktivt med 1 , hvad dex sker af storpolitiske begivenheder. Men hans kone Agnes forstår ikke, at hans politiske engagement går forud for hende og bornene, og der komer en splittelse mellem dem. HJeme hos grisehandleren og hans kone er der glade over, at den tyske forfattex Herbert schmidt for en stund ex vendt tilbage til korsbak. Men storst glade vakkex hans tilbagevenden hos Vickl Arnesen, der har forelsket sig i ham.

Episode 16. "Lauras store dag" (Forä 1940)

Laura har tjent Familien Varnes $125 \mathrm{ar}$, og i den anledning drager hun til København for at fä overrakt den kongelige fortjenstmedalje for lang og tro tjeneste. Turen til Hovedstaden er en oplevelse for Laura, men dagens mange begivenheder har givet hende stof til eftertanke, og allerede dagen efter vakker hun bestyrtelse 1 det varnzske hjem ved for føxste gang 125 àr at gøre oprox over sine kăr. Hun siger op. Samme dag rykker tyskerne ind i Danmark. Beboerne $i$ Korsbak har endnu ingen klar holaning til besattelsestropperne. Stort set holder man en lav profil $i$ forholdet til tyskerne, men for flygtningen 
Herbert ex stuationen pludselig blevet alvorlig og ham wa forlade Korsbak og Vicki. Efter at have arbejdet som 1,s kogekone en tid, vender Laura tilbage til. det varnaske hjem.

Episode 17. "De voksnes rakker" (Sommer 1941 - forår 1942)

Varnas- og skjern-bornene er ved at blive voksne og virik varnas har et godt $\emptyset j$ til Mads skjerns datter Ellen. Men denne forbindelse er ikke velkommen 1 varneshjemnet, og da ulrik efter afskedsfest for Daniel skjern $i$ noget beruset tilstand kommex til at anbxinge en praservativautomat pa badeverelset hos Varnas, ser Maude en leflighed til at fa sendt vlrik bort fra Korsbak. Ellen skjern møder på en somnerferle til Skagen den unge Mogens Lamborg, som kommer fra en af landets rigeste familiex, og de bliver forelskede. Mads skjern er ovenud begejstret for denne relation, mens Ingeborg ex dybt bekymret over Mogens' fars aktiver og interesser 1 Dansk Arbejdsgiverforening og Dansk-TyskForening. Ingeborg făr ogsả andre problemer 1 forbindelse med besattelsen, Ldet hendes tidligere mand atter dukker op - og nu som nazist. Tre markante Korsbakskikkelser dør. Det er Fru Fernando Møhge, oberst Hackel og hx. Schwann. Kristen og Iben skjerns agteskab hangex $i$ en meget tynd trad, og Røde konmer i vanskelighedex p.g.a. sin kommunistiske overbevisning. Jagten på kommunisterne er găet ind.

Episode 18. "Hr. Stein" (1943)

Korsbak hax fẳet kxigen pả nart hold. Bogholderen i Korsbak Bank, hr. Stein, ex jøde og da jagten på de danske jødex ex gäet ind, kommer tyskerne til korsbak for at få fat 1 stein. Men fuglen er flojet, hjulpet af Maude Varnas, der aldeles uselvisk udforer sit livs helteda, af Daniel og af Kristen skjern, der forsyner stein med nye legitimationspapirer, sâ han kan gå under jorden. Maudes hjælp til stein ex en absolut modsatning til hendes sadvanlige pylrethed, og hun far en vis genoprejsning. Doktor Hansen, Kxisten Skjern og Elisabeth Frils er aktive $i$ kampen mod besattelsesmagten. Familien skjern holder bryllup for datteren Ellen og Mogens Iamborg, og ulxik varnas ex ulykkelig over giftemalet, som han menex Maude delvis har noget af skylden for. Bag morklagningsgardinerne gor Misse forberedelse til sit livs forste hyrdetime. Efter sin mors dod har hun kastet sin kærlighed på den pensionerede larer Andersen. 


\section{LITTERATURLISTE}

Andersen, Liss1 Ørvad, m. fl. : Pegneserler. En ekspansions historie. Grena 1973.

Arentoft, Fleming: Provins som ldelogi. In Provins - et poliisk problem. Arhus 1977.

Bang, Johann m.f1.: Moral, morallsme, gadespejl og sognebånd. In: Kritik 56. København 1981.

Buselmeler, Michael: Massenunterhaltung im Rahmen vor Arbeit una Frelze1t. In: Das glückllche Bewusstseln. München 1974.

Carisen, Jorgen m. I1. Kapltallsme, behov og civilisation, bd. I-II. Arhus $198 \overline{0}$.

Falk, Jørgen: Selv det at vare klog er kun den halve klogskab. In: Hug! nr. 18. Kфbenhavn 1978.

Fausing, Bent: Fascinationsformer. Kфbenhavn 1977.

Holter, Harriet, m. f1.: Familien 1 klassesamfundet. Oslo 1975.

Kieselberg, Steffen: Mandenes historle. København 1979.

Krovoza, Alfred: Inderliggørelsen af det abstrakte arbejdes normer og sanselighedens skabne. In: Soclallsationsforskning. København 1978.

Lefebvre, Henr1: Kritik des Alltagslebens. Kronberg 1977.

Mortensen, Frands, m.f1. (red.): Underholdning 1 TV. Dansk massekommunikationsforskning 1. Kфbenhavn 1981.

Mølgard, Jan: Tilbage til den indre hjemstavn - serier og serieforbrug. In: Krit1k 56. Kobenhavn 1981.

Negt, Oscar, Alexander Kluge: offentllghet og erfaring. Gren⿳⺈ 1974 .

Nissen, Dan: Morten Korch-flimatiseringer. Mellem national samling og truet småborgerskab. In: Visuel kommunikation. Kobenhavn 1980.

Prokop, Ulrike: Kvindelig livssammenhæng. Grena 1978.

Reyher, Ulrich: Massmedia och subversiv längtan. In: Mass-konmunikation och medvetande produktion, red, $R$. Cheesman og C. Kyhn. København 1975.

Shorter, Edward: Kernefamiliens historle. Røbenhavn 1979.

Zerlang, Martin: Bøndernes klassekamp 1 Danmark. København 1976.

Nanna Frost, Holger Knudsen, Sine Dalsgaard Kristensen og Peter Rosenlund $s \phi r e n s e n$ er hovedfagsstuderende 1 dansk ved Nordisk Institut, Arhus universitet. 


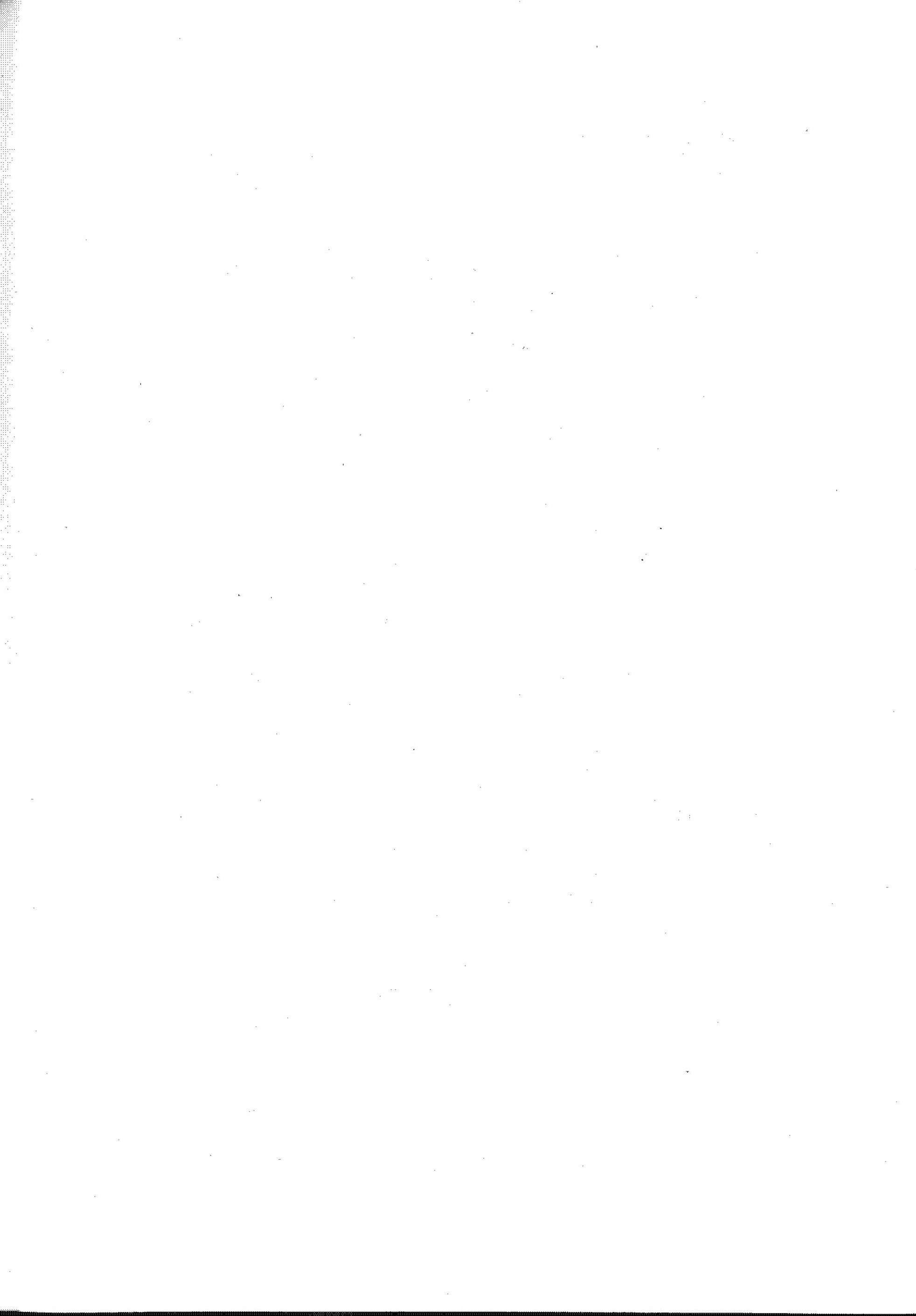

